\title{
Characterization of Delayed Rectifier Kv Channels in Oligodendrocytes and Progenitor Cells
}

\author{
Bernard Attali, ${ }^{1}$ Ning Wang, ${ }^{2}$ Alexandra Kolot, ${ }^{1}$ Alexander Sobko, ${ }^{1}$ Vera Cherepanov, ${ }^{1}$ and Betty Soliven ${ }^{2}$ \\ ${ }^{1}$ Department of Neurobiology, The Weizmann Institute of Science, Rehovot 76100, Israel, and ${ }^{2}$ Department of Neurology \\ and Committee on Neurobiology, The Brain Research Institute, University of Chicago, Chicago, Illinois 60637
}

\begin{abstract}
We examined the molecular identity of $\mathrm{K}^{+}$channel genes underlying the delayed rectifier $\left(I_{K}\right)$ in differentiated cultured oligodendrocytes (OLGs) and oligodendrocyte progenitor (OP) cells. Using reverse transcription-PCR cloning, we found that OP cells and OLGs expressed multiple Kv transcripts, namely $\mathrm{Kv1.2,} \mathrm{Kv1.4,} \mathrm{Kv.1.5,} \mathrm{and} \mathrm{Kv1.6.} \mathrm{Immunocytochemical} \mathrm{and}$ Western blot analyses revealed that Kv1.5 and Kv1.6 as well as Kv1.2 and Kv1.4 channel proteins could be detected in these cells, but definitive evidence for functional $\mathrm{K}^{+}$channel expression was obtained only for the Kv1.5 channel. In addition, mRNA and immunoreactive protein levels of both Kv1.5 and Kv1.6 channels were significantly lower in differentiated OLGs
\end{abstract}

It is recognized that cells of the oligodendrocyte lineage express voltage-dependent $\mathrm{K}^{+}$channels (Soliven et al., 1988; Sontheimer and Kettenmann, 1988; Barres et al., 1990). The expression of a given $\mathrm{K}^{+}$channel repertoire is correlated with a specific functional stage of oligodendrocyte development (Soliven et al., 1988, 1989; Sontheimer et al., 1989). Depending on the cell preparation (slices or primary cultures) and the stage of development, these cells express either time-independent $\mathrm{K}^{+}$currents with almost linear $I-V$ curves or time-dependent voltage-gated outwardly and inwardly rectifying $\mathrm{K}^{+}$conductances (Sontheimer and Kettenmann, 1988; Soliven et al., 1989; Berger et al., 1991; Chvatal et al., 1995; Soliven and Wang, 1995). Voltage-dependent $\mathrm{K}^{+}$outward currents in rat differentiated oligodendrocytes (OLGs) and oligodendrocyte progenitor (OP) cells are minimally inactivating or nonactivating $\left(I_{\mathrm{K}}\right)$, although transient $I_{\mathrm{A}}$-like currents have been observed in the latter.

Recent cloning studies have demonstrated that the diversity in the conductance, gating mechanisms, and pharmacology of $\mathrm{K}^{+}$ channels reflects the diversity in their molecular structures and assemblies. Three main $\mathrm{K}^{+}$channel archetypes could be distinguished. The first superfamily comprises the Shaker archetype of $\mathrm{K}^{+}$channels, which includes the voltage-gated $\mathrm{K}^{+}$channel subfamily, $\mathrm{Ca}^{2+}$-sensitive $\mathrm{K}^{+}$channels, and the erg channel subfamily (Salkoff and Jegla, 1995; Kohler et al., 1996). In this super-

Received March 10, 1997; revised Aug. 5, 1997; accepted Aug. 13, 1997.

This work was supported by grants to B.A. from Israel Cancer Research Fund (Research Career Development Award) and the Ebner family foundation; and by National Institutes of Health Grant PO1 NS24575, National Multiple Sclerosis Society Grant RG2195-C4, and in part by grants from Spinal Cord Research Foundation and Brain Research Foundation to B.S. B.A. is an incumbent of the Philip Harris and Gerald Ronson Career Development Chair.

Correspondence should be addressed to Dr. Betty Soliven, Department of Neurology, The University of Chicago, 5841 South Maryland, Chicago, IL 60637, or to Dr. Bernard Attali, Department of Neurobiology, The Weizmann Institute of Science, Rehovot 76100, Israel.

Copyright (C) 1997 Society for Neuroscience $0270-6474 / 97 / 178234-12 \$ 05.00 / 0$ when compared with levels in OP cells. Proliferation of OP cells was inhibited by $\mathrm{K}^{+}$channel blockers, but not by incubation with either Kv1.5 or Kv1.6 antisense oligonucleotides. We conclude that (1) $I_{\mathrm{K}}$ in OP cells and OLGs is encoded partly by Kv1.5 subunits, possibly forming heteromultimeric channels with Kv1.6 or other Kv subunits; and (2) inhibition of Kv1.5 or Kv1.6 channel expression alone does not prevent mitogenesis. Concomitant inhibition of other $\mathrm{Kv}$ channels underlying $I_{\mathrm{K}}$ may be necessary for OP cells to exit from cell cycle.

Key words: ion channels; delayed rectifier; glia; oligodendrocyte progenitors; proliferation

family the core region of each subunit is formed by six putative transmembrane domains (S1-S6) and an H5 segment between S5 and S6, which mainly constitutes the channel pore. The second archetype includes channels of the inward rectifier type, Gprotein-coupled and ATP-sensitive $\mathrm{K}^{+}$channels with two hydrophobic segments (M1 and M2) and a linker region (H5), homologous to the H5 segment of Shaker $\mathrm{K}^{+}$channels (Doupnik et al., 1995). The third group represents a novel $\mathrm{K}^{+}$channel architecture that exhibits the unique feature of having in tandem two pore motifs (Salkoff and Jegla, 1995). In glial cells, members of $\mathrm{K}^{+}$ channels belonging to the Shaker Kv1 family have been described. Three $\mathrm{K}^{+}$channels genes, Kv1.1, Kv1.2, and Kv1.5, have been characterized in sciatic nerves and are thought to be derived from myelinating Schwann cells (Chiu et al., 1994; Mi et al., 1995). Recently, partial sequences of two inward rectifiers Kir2.1 (IRK1) and Kir1.1 (ROMK1) have been amplified by PCR from OLG cDNAs (Karschin and Wischmeyer, 1995). However, the molecular structure of most $\mathrm{K}^{+}$channels in OLGs and OP cells has not yet been characterized.

The goals of this study were to (1) elucidate the molecular identity of $\mathrm{K}^{+}$channel genes underlying the delayed rectifying $\mathrm{K}^{+}$current $\left(I_{\mathrm{K}}\right)$ in OP cells and OLGs and (2) to investigate the role of $I_{\mathrm{K}}$ in the proliferation of OP cells. We found that Kv1.5 channel is a major component underlying $I_{\mathrm{K}}$ in OP cells and OLGs. Our results also identify $I_{\mathrm{K}}$ channels as a key component involved in the regulation of OP proliferation.

\section{MATERIALS AND METHODS}

Cell culture. For clarity, we have used the term oligodendrocyte progenitor (OP) cells to include the bipolar $\mathrm{A} 2 \mathrm{~B}^{+}$cells $(\mathrm{O}-2 \mathrm{~A})$ and the multipolar $\mathrm{O}^{+}{ }^{+} \mathrm{GalC}^{-}$cells and the term differentiated oligodendrocytes (OLGs) to include $\mathrm{GalC}^{+}$cells. Two types of OLG cultures were used in this study: neonatal rat OLG cultures and postnatal day (P) 21 rat OLG cultures. Neonatal mixed glial cells were isolated according to the method described by McCarthy and de Vellis (1980). The collected cells were cultured in DMEM supplemented with $10 \%$ fetal bovine serum 
(FBS). After 10-12 d, O-2A progenitors were detached by overnight shaking, were collected, and were preplated for $1 \mathrm{hr}$ to remove contaminating macrophages and astrocytes. Floating cells were collected and plated on poly-L-lysine-coated dishes. At this stage the cells were bipolar and $\mathrm{A} 2 \mathrm{~B} 5{ }^{+}$. The culture medium was changed the day after plating to serum-free medium (SFM) supplemented with $5 \mu \mathrm{g} / \mathrm{ml}$ insulin, $5 \mu \mathrm{g} / \mathrm{ml}$ transferrin, and $5 \mathrm{ng} / \mathrm{ml}$ sodium selenite (ITS; Sato 1 medium) or low-serum-containing medium (0.5\% FBS plus ITS). As O-2A progenitors underwent differentiation under these conditions, they became multipolar and acquired $\mathrm{O}_{4}^{+}$immunoreactivity before the expression of galactocerebroside $(\mathrm{GalC})$. After $5 \mathrm{~d}$, the secondary cultures contained 90-95\% OLGs ( $\mathrm{GalC}^{+}$cells). When indicated, O-2A cells were plated in Sato 2 medium [Sato 1 supplemented with $0.5 \%$ FBS, $5 \mathrm{ng} / \mathrm{ml}$ plateletderived growth factor (PDGF), and $5 \mathrm{ng} / \mathrm{ml}$ basic fibroblast growth factor (bFGF)].

P21 OLGs were isolated via the Percoll-sucrose gradient method, as described previously (Soliven et al., 1993). The cells were preplated for $1 \mathrm{~d}$ in culture medium (MEM plus $10 \%$ horse serum, $0.4 \%$ glucose, and $1 \%$ penicillin-streptomycin). On the next day the floating cells were removed and plated onto poly-L-lysine-coated Petri dishes at low density. By 6-7 d in vitro (after one to two treatments with $10 \mu \mathrm{M}$ cytosine arabinoside), the purity of OLG cultures was ascertained to be $\geq 95 \%$, using a polyclonal rabbit anti-galactocerebroside antibody (Advanced Immunochemical Services, Long Beach, CA).

RNase protection analysis. Total RNA was extracted from cultured OP cells and OLGs according to the method described by Chomczynski and Sacchi (1987). Kv1.5 and Kv1.6 antisense cRNA probes were synthesized in vitro from the linearized cDNAs by using $\mathrm{T} 7$ and $\mathrm{T} 3 \mathrm{RNA}$ polymerases (Stratagene, CA), respectively, and uridine triphosphate $\left(\left[\alpha^{32} \mathrm{P}\right] \mathrm{UTP}\right.$, $4000 \mathrm{Ci} / \mathrm{mmol}$; Amersham, Little Chalfont, UK). The template cDNA probes were derived by linearizing $\mathrm{pBS} / \mathrm{Kv} 1.5$ and $\mathrm{pBS} / \mathrm{Kv} 1.6$ plasmids with $X b a \mathrm{I}$ and $X h o \mathrm{I}$, respectively. The labeled Kv1.5 and Kv1.6 cRNA probes $\left(2.5 \times 10^{5} \mathrm{cpm}\right)$ of 430 and 563 base lengths, respectively, were hybridized separately with $20 \mu \mathrm{g}$ of total RNA in $80 \%$ formamide, $40 \mathrm{~mm}$ PIPES, $\mathrm{pH}$ 6.4, $1 \mathrm{~mm}$ EDTA, and $0.4 \mathrm{M} \mathrm{NaCl}$ for $14 \mathrm{hr}$ at $45^{\circ} \mathrm{C}$. To allow for quantitation of the input RNA, we included a labeled cRNA probe encoding the housekeeping gene glyceraldehyde phosphate dehydrogenase (GAPDH) in the hybridization mixture. Then the duplex RNA hybrids were digested with RNase A and RNase T1 as described (Sambrook et al., 1989). The RNase-resistant fragments were electrophoresed on $6 \%$ polyacrylamide $7 \mathrm{~m}$ urea gels and autoradiographed as previously described (Matus-Leibovitch et al., 1996). Data were quantified by scanning the labeled bands with a Umax Powerlook II densitometer (Taipei, Taiwan) and Adobe Photoshop software. The optical densities of Kv channel mRNA fragments were normalized to the GAPDH signal.

Reverse transcription-PCR (RT-PCR). First-strand cDNA synthesis was performed under the following conditions: $3-5 \mu \mathrm{g}$ of total RNA was mixed in diethylpyrocarbonate-treated water with $0.5 \mu \mathrm{g}$ of random hexamer primer (Pharmacia, Uppsala, Sweden), and the mixture was incubated for $10 \mathrm{~min}$ at $70^{\circ} \mathrm{C}$ and chilled on ice. Then a first-strand reaction mix buffer containing (in $\mathrm{mM}$ ) 45 Tris, $\mathrm{pH} \mathrm{8.3,68 \textrm {KCl } , 1 5}$ dithiothreitol (DTT), and $9 \mathrm{MgCl}_{2}$, with a $1.8 \mathrm{mM}$ concentration of each deoxyribonucleotide (dNTP), $0.08 \mathrm{mg} / \mathrm{ml} \mathrm{BSA}, 100 \mathrm{U}$ of RNasin, and 50 $\mathrm{U}$ of cloned FPLC pure Murine Reverse Transcriptase (Pharmacia) was added and incubated for $1 \mathrm{hr}$ at $37^{\circ} \mathrm{C}$. After the first-strand cDNA synthesis was completed, the reverse transcriptase was inactivated by heating the reaction to $95^{\circ} \mathrm{C}$ for $5 \mathrm{~min}$. Five microliters of the first-strand cDNA synthesis reaction were used for PCR, which was performed in a buffer containing $50 \mathrm{~mm} \mathrm{KCl}, 10 \mathrm{~mm}$ TRIS- $\mathrm{HCl}, \mathrm{pH} 9.0$, at $25^{\circ} \mathrm{C}, 0.1 \%$ Triton X-100, a $0.2 \mu \mathrm{M}$ concentration of each dNTP, a $1 \mu \mathrm{M}$ concentration of each upstream and downstream primer, and 2.5 U of Taq DNA polymerase (Promega, Madison, WI).

For RT-PCR cloning of Shaker-related outward $\mathrm{K}^{+}$channels in OP cells and OLGs, we used degenerate oligonucleotides encoding conserved domains of Shaker-related channel sequences. The upstream primer [5'AAYGAGTACTTCTTYGAYMG-3'] corresponded to a conserved region NEYFFDR, located upstream of the first transmembrane domain S1. The downstream primer [5'-NCCRTANCCNRNNGWNGA-3'] corresponded to the most conserved H5 pore signature sequence TTVGYG. After 35 PCR cycles consisting of $30 \mathrm{sec}$ denaturation at $94^{\circ} \mathrm{C}, 150 \mathrm{sec}$ annealing at $50^{\circ} \mathrm{C}$, and $60 \mathrm{sec}$ extension at $72^{\circ} \mathrm{C}$, the amplified products were fractionated by $1 \%$ agarose gel electrophoresis, purified, subcloned into the pGEMT vector (Promega), and sequenced. To exclude possible PCR contaminations (genomic or plasmidic), we performed the PCR reaction with primers in the absence of input RNA/cDNA template and reverse tran- scriptase. In addition, a reaction containing all PCR reagents and input RNA, but without reverse transcriptase, also was performed systematically.

For semiquantitative RT-PCR, the reverse transcription was performed as described above. Unique primer pairs encoding the specific $3^{\prime}$ coding region of the respective Kv channels were used for RT-PCR amplification. The PCR reaction was cycled as follows: denaturation for $60 \mathrm{sec}$ at $95^{\circ} \mathrm{C}$, annealing for $90 \mathrm{sec}$ at $50^{\circ} \mathrm{C}$, and extension for $60 \mathrm{sec}$ at $72^{\circ} \mathrm{C}$ for 35 cycles. The PCR primers were designed according to the rat cDNA channel sequences: Kv1.2 sense 5'-CACCGGGAGACAGAGGGA-3' (1249-1266) and Kv1.2 antisense 5'-TCAGACATCAGTTAACAT-3' (1479-1497); Kv1.4 sense 5'-CCATACCTACCTTCTAAT-3' (2255-2273) and Kv1.4 antisense 5'-TCACACATCAGTCTCCAC-3' (2442-2459); Kv1.5 sense 5'-CATCGGGAGACAGACCAC-3' (18341851) and Kv1.5 antisense 5'-TTACAAATCTGTTTCCCG-3' (20892107); Kv1.6 sense 5'-CACTACTTCTACCACCGA-3' (1817-1834) and Kv1.6 antisense 5'-TCAAACCTCGGTGAGCAT-3' (2006-2023). A semiquantitative PCR analysis was performed to quantify the input mRNA and related cDNA of the various samples. The coamplification of an internal control housekeeping S16 ribosomal protein mRNA was performed by using an upstream primer (S16 sense, 5'-AGGAGCGATTTGCTGGTG-3') and a downstream primer (S16 antisense, 5'CAGGGCCTTTGAGATGGA-3'), which amplified a 102 bp cDNA fragment. Equal aliquots of each PCR reaction were removed at various cycle numbers and analyzed by $1.2 \%$ agarose gel electrophoresis, Southern-blotted onto nylon membranes, and probed with a unique internal $\left[{ }^{32} \mathrm{P}\right]$-labeled oligonucleotide. Data were quantified by scanning the labeled bands as above, and the optical densities of Kv channel bands were normalized to the S16 signal.

In situ hybridization. Templates, subcloned into pBluescript $\mathrm{SK}^{-}$plasmid, were linearized with the corresponding restriction enzymes (XbaI for Kv1.5 antisense orientation and Kv1.6 sense orientation or EcoRI for Kv1.5 sense orientation and Kv1.6 antisense orientation). Digoxigeninlabeled single-stranded RNA probes in the antisense or sense orientation were synthesized from linearized templates that used T3 or T7 RNA polymerases in the presence of digoxigenin UTP (Boehringer Mannheim, Mannheim, Germany) according to the manufacturer's instructions. In situ hybridization experiments were performed as described (Litman et al., 1993) with some modifications. Briefly, cells grown on coverslips were fixed with $4 \%$ paraformaldehyde containing $4 \%$ sucrose for $10 \mathrm{~min}$ and then rinsed with PBS, transferred to $70 \%$ ethanol, and stored at $4^{\circ} \mathrm{C}$ until use. Before hybridization, cells were rehydrated sequentially and prehybridized for $2-3 \mathrm{hr}$ at $50^{\circ} \mathrm{C}$ in hybridization buffer consisting of $50 \%$ formamide, $4 \times \mathrm{SSC}(600 \mathrm{~mm} \mathrm{NaCl}$ and $60 \mathrm{~mm}$ sodium citrate), $2 \times$ Denhardt's solution, $20 \mathrm{~mm}$ Tris, $\mathrm{pH} 8,5 \mathrm{~mm}$ EDTA, $10 \%$ dextran sulfate, $0.1 \%$ sodium dodecyl sulfate, and $100 \mu \mathrm{g} / \mathrm{ml}$ salmon sperm DNA.

Hybridization was allowed to proceed in a humidified chamber for 16 $\mathrm{hr}$ at $50^{\circ} \mathrm{C}$. Coverslips were hybridized with hybridization buffer containing $1 \mathrm{ng} / \mathrm{ml}$ digoxigenin-labeled Kv1.5 or Kv1.6 cRNA probes. After hydrolysis of nonspecifically hybridized probe by $20 \mathrm{mg} / \mathrm{ml}$ RNase A in $500 \mathrm{~mm} \mathrm{NaCl}$ and $10 \mathrm{~mm}$ Tris, $\mathrm{pH} 8$, for $30 \mathrm{~min}$ at $37^{\circ} \mathrm{C}$, coverslips were rinsed subsequently in $2 \times$ SSC, $2 \times$ SSC plus $0.1 \%$ SDS, and $1 \times$ SSC twice for $15 \mathrm{~min}$ at $50^{\circ} \mathrm{C}$ for each sequence. An anti-digoxigenin antibody conjugated to alkaline phosphatase was applied for $30 \mathrm{~min}$ at room temperature (1:1000), and nitroblue tetrazolium/bromocresol IP substrate color development was performed. The reaction was monitored by bright-field microscopy and stopped by the addition of $10 \mathrm{~mm}$ Tris, $\mathrm{pH}$ 7.5, and $1 \mathrm{~mm}$ EDTA for 15-90 min. Coverslips were examined under bright-field microscopy.

Antibodies. Polyclonal antibodies were raised in rabbits against a specific C-terminal region downstream of the S6 transmembrane segment of Kv1.5 and Kv1.6 channels. The antigens were generated as fusion proteins with glutathione $S$-transferase (GST) by PCR amplification and the subcloning of 273 and 206 bp DNA fragments encoding Kv1.5 (amino acids 513-602) and Kv1.6 (amino acids 463-530) channel proteins into the bacterial expression vector pGEX-3X (Pharmacia). The antisera were depleted of anti-GST antibodies by affinity chromatography on immobilized GST and then purified on nitrocellulose strips containing the purified channel proteins. Anti-Kv1.2 and anti-Kv1.4 polyclonal antibodies were purchased from Alomone Labs (Jerusalem, Israel), raised against GST-rat Kv channel fusion proteins (aa 417-498 and aa 589-655 for Kv1.2 and Kv1.4 channels, respectively), and affinity-purified.

Western blot analysis. Samples were resolved by SDS-PAGE and electroblotted to nitrocellulose. Blots were blocked with $10 \%$ nonfat milk in PBS containing $0.05 \%$ Tween 20 for $1 \mathrm{hr}$ at room temperature. The blots 
were incubated with antibodies against Kv channels (diluted at 1:400 for Kv1.2, 1:300 for Kv1.4, 1:2000 for Kv1.5, and 1:300 for Kv1.6) for $4 \mathrm{hr}$ at room temperature and then after extensive wash for $1 \mathrm{hr}$ with goat anti-rabbit horseradish peroxidase-conjugated secondary antibodies (Jackson Laboratories, West Grove, PA), followed by enhanced chemiluminescence detection (ECL; Amersham). When indicated, antibodies against $\mathrm{Kv}$ channels were preadsorbed with the recombinant channelGST fusion proteins ( $1 \mu \mathrm{g} / \mathrm{ml}$ for $30 \mathrm{~min}$ at room temperature) to check for specificity. Immunoreactive proteins were scanned and quantified as above.

Immunocytochemistry. For $\mathrm{O}^{+}$immunolabeling studies, cells were incubated sequentially at $37^{\circ} \mathrm{C}$ with monoclonal $\mathrm{O} 4^{+}$(1:50 dilution; Boehringer Mannheim) and goat anti-mouse (FITC-conjugated at 1:100 dilution; Jackson Laboratories, West Grove, PA) antibodies in PBS containing $2 \%$ normal goat serum (NGS) for $30 \mathrm{~min}$. Subsequently, cells were fixed in cold methanol for $10 \mathrm{~min}$ at $-20^{\circ} \mathrm{C}$, washed, and mounted for fluorescence microscopy.

For studies involving A2B5 ${ }^{+}$(1:20 dilution; Boehringer Mannheim), anti-MBP (1:10 dilution; Serotec, Oxford, UK), and anti-K ${ }^{+}$channel antibodies (1:500 and 1:100 dilution for Kv1.5 and Kv1.6, respectively), cells first were fixed for $20 \mathrm{~min}$ in PBS containing $4 \%$ paraformaldehyde, washed, and permeabilized (except for $\mathrm{A} 2 \mathrm{~B} 5^{+}$) with PBS containing $0.2 \%$ Triton X-100 and $10 \%$ NGS for $20 \mathrm{~min}$ at room temperature. Then primary antibodies were added in PBS containing $2 \%$ NGS for $3 \mathrm{hr}$ at room temperature and washed out; the cells were incubated finally with secondary antibodies (goat anti-mouse or anti-rabbit FITC-conjugated antibodies at 1:100 dilution) for $1 \mathrm{hr}$ at room temperature in the dark. Immunofluorescence in human embryonic kidney (HEK) 293 cells was performed as above after transfection of the Kv1.5 or Kv1.6 cDNA (into prCMV-based vectors; Invitrogen, Leek, The Netherlands) by the calcium phosphate method (Sambrook et al., 1989). As a check for specificity, the anti-K ${ }^{+}$channel antibodies were preadsorbed with the recombinant channel-GST fusion proteins, as described above.

Sense and antisense phosphorothioate oligonucleotides (ODNs). The following phosphorothioate ODNs corresponding to the Kv1.5 channel sequence were used: ODN4 (5'-GTTTATGAGGACCCG-3') antisense ODN encoding the $\mathrm{Kv} 1.5 \mathrm{NH}_{2}$ terminus (position 630-648 of the rat cDNA sequence); ODN18 (5'-ATCTCCATGGTCCGG-3') and ODN19 (5'-CCGGACCATGGAGAT-3') antisense and sense ODNs, respectively, spanning the Kv1.5 initiation methionine; ODN16 (5'TTTTCTGCTGCCTGGTA-3') sense ODN encoding the 5' untranslated region of the Kv1.5 cDNA (position 40-56); ODN20 (5'-TGACATGAGATCGGAGAA-3') and ODN21 (5' ${ }^{\prime}$ TTCTCCGATCTCATGTCA- $3^{\prime}$ ) sense and antisense ODNs, respectively, spanning the Kv1.6 initiation methionine.

$\left[{ }^{3} H\right]$ Thymidine incorporation. O-2A progenitors obtained from shaking the mixed glial cultures were plated at 8000 cells/well in 24-well plates. For each experiment the purity of the culture was verified by immunocytochemistry, using $\mathrm{A} 2 \mathrm{~B} 5^{+}$and $\mathrm{O}^{+}{ }^{+}$monoclonal antibodies as well as anti-GFAP antibodies for estimating the contaminating astrocytes. Phosphorothioate Kv1.5 and Kv1.6 ODNs were added first for 24 hr. Then $\left[{ }^{3} \mathrm{H}\right]$ thymidine $(0.2 \mathrm{mCi} /$ well $)$ was added for another $24 \mathrm{hr}$. Cells subsequently were washed and harvested; radioactivity was determined by a liquid scintillation counter. $\mathrm{K}^{+}$channel blockers were added together with $\left[{ }^{3} \mathrm{H}\right]$ thymidine. Incorporation of $\left[{ }^{3} \mathrm{H}\right]$ thymidine was determined in cells grown in serum-free medium (Sato 1) as well as in Sato 1 medium supplemented with PDGF and bFGF at $5 \mathrm{ng} / \mathrm{ml}$ each (Sato 2). The effects of the channel blockers and the phosphorothioate ODNs were tested in Sato 2 medium. The results were expressed as a percentage of maximal control proliferation obtained as the difference between $\left[{ }^{3} \mathrm{H}\right]$ thymidine incorporation in cells grown in Sato 1 and Sato 2 medium. Electrophysiology. Current recordings were obtained via the whole-cell configuration of the patch-clamp technique, as previously described (Soliven et al., 1988). The pipette resistance ranged from 2-5 M 2 . Cells were studied at room temperature. For the recording of $\mathrm{K}^{+}$currents, the bathing solution consisted of the following (in $\mathrm{mm}$ ): $140 \mathrm{NaCl}, 5.4 \mathrm{KCl}$, $2 \mathrm{CaCl}_{2}, 1 \mathrm{MgCl}_{2}$, and $10 \mathrm{HEPES}, \mathrm{pH} 7.3$ (normal bath solution). Pipette (intracellular) solutions contained (in mM) $140 \mathrm{KCl}, 2 \mathrm{CaCl}_{2}, 2$ $\mathrm{MgCl}_{2}, 11$ EGTA, and $10 \mathrm{HEPES}, \mathrm{pH}$ 7.3. For cell population studies a dish of untreated cells was included for each set of experimental conditions to control for culture-to-culture variability in current densities. When indicated, the ODNs that were used for recording corresponded to those described above. Current records were filtered at $2 \mathrm{kHz}$, using an eight-pole Bessel filter, and sampled at $5 \mathrm{kHz}$.

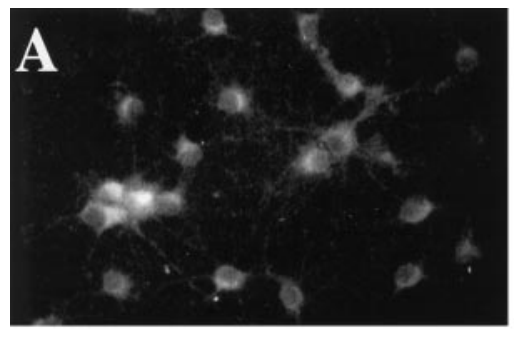

Figure 1. Immunofluorescence analysis of neonatal oligodendrocyte cultures and representative ionic current patterns in these cells. Shown are O-2A progenitors ( $16 \mathrm{hr}$ old) labeled with the $\mathrm{A} 2 \mathrm{~B} 5^{+}$antibody $(A)$ and corresponding whole-cell current recordings illustrating $I_{\mathrm{K}}$ plus $I_{\mathrm{A}}(B)$. Also shown are multipolar progenitors $(2 \mathrm{~d}$ old $)$ labeled with $\mathrm{O}^{+}{ }^{+}$antibody $(C)$ and corresponding current recordings illustrating $I_{\mathrm{K}}$ plus $I_{\mathrm{Kir}}(D)$. Finally, shown are 5-d-old cells (OLGs) labeled with anti-MBP antibody $(E)$ and corresponding current recordings illustrating $I_{\mathrm{i}}$ and $I_{\mathrm{Kir}}(F)$. Voltage pulses of $360 \mathrm{msec}$ duration were stepped from a holding potential $\left(V_{\mathrm{h}}\right)$ of -40 and $-80 \mathrm{mV}$ in $20 \mathrm{mV}$ increments/decrements, except for the first two pulses that were $\pm 5 \mathrm{mV}$ from the holding potential. Scale bar, $35 \mu \mathrm{m}$.
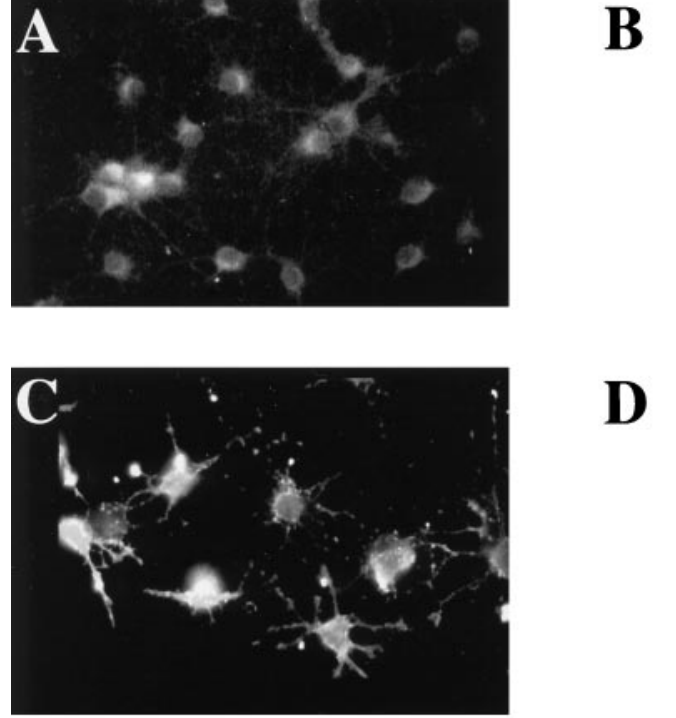

$\mathrm{I}_{\mathrm{K}}+\mathrm{I}_{\mathrm{A}}$

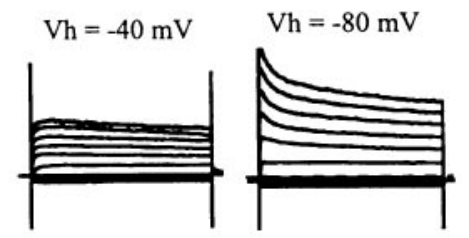

$D I_{K}+I_{K i r}$
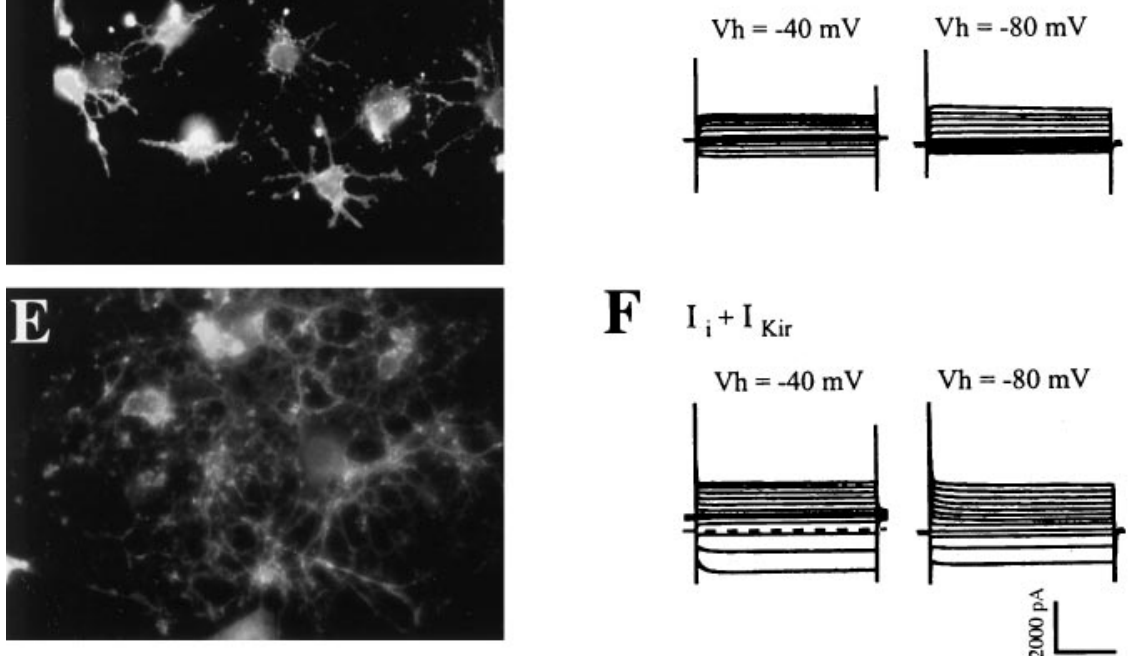

F $\quad I_{i}+I_{\text {Kir }}$

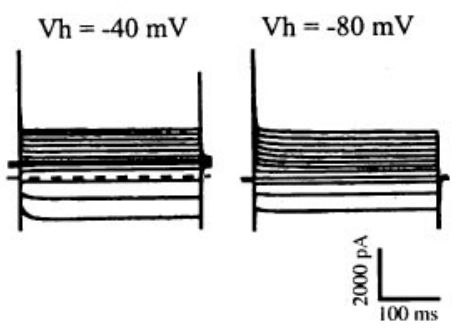


A

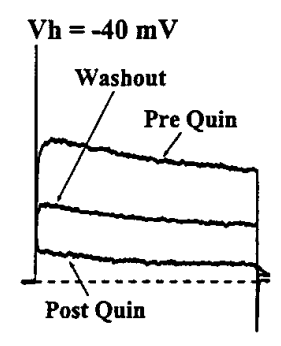

C

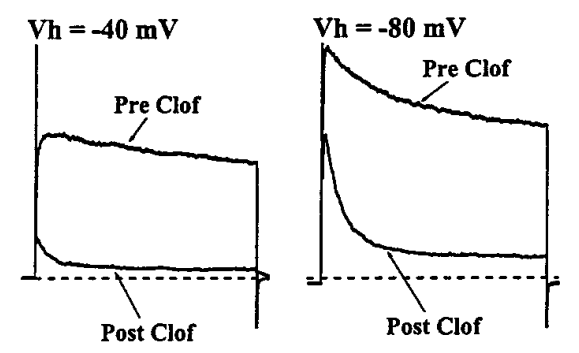

B

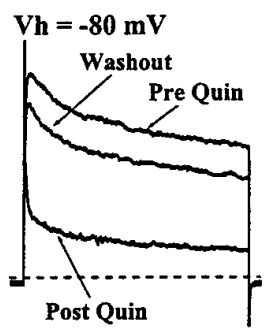

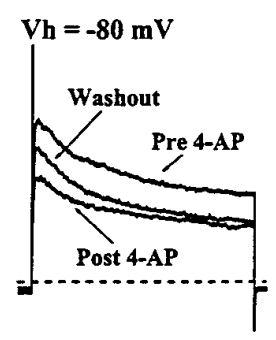

D

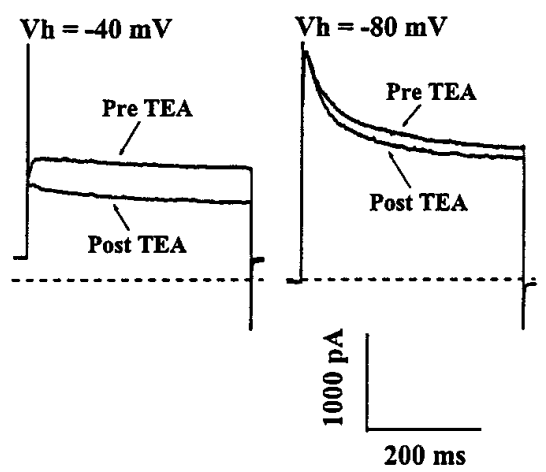

Figure 2. Examples of whole-cell recordings illustrating the inhibition of $I_{\mathrm{K}}$ from OP cells by $\mathrm{K}^{+}$ channel blockers. $A$, Quinidine $(50 \mu \mathrm{M}) . B, 4$-AP $(0.3 \mathrm{~mm}) . C$, Clofilium $(1 \mu \mathrm{M}) . D$, TEA $(2 \mathrm{mM})$. Pulse protocols are as described in Figure 1. Only two to three current traces are shown to illustrate $\mathrm{K}^{+}$currents activated by depolarizing pulses to $+60 \mathrm{mV}$ before and after perfusion with $\mathrm{K}^{+}$ channel blockers.
Data analysis. Results were expressed as mean \pm SEM, with the number of experiments in parentheses. In proliferation assays, RNase mapping, semiquantitative RT-PCR, and Western blotting experiments, statistical differences between control and test values were analyzed by Student's $t$ test. In electrophysiological experiments, statistical significance of the results was determined by ANOVA and $\mathrm{F}$ tests.

\section{RESULTS}

\section{$I_{K}$ expressed by cells of oligodendrocyte lineage resembles those encoded by members of the Shaker family}

Immunocytochemical markers allow for the distinction of three consecutive phenotypically defined stages of OLG development in vitro: the bipolar A2B5 ${ }^{+} 04^{-} \mathrm{GalC}^{-}$glial precursor, multipolar $\mathrm{A} 2 \mathrm{~B} 5{ }^{+} \mathrm{O} 4{ }^{+} \mathrm{GalC}^{-}$OLG progenitor, and complex processbearing $\mathrm{O}^{+}{ }^{+} \mathrm{GalC}^{+} \mathrm{MBP}^{+}$OLGs (Dubois-Dalcq, 1987; Gard and Pfeiffer, 1989). In this study we used the term OP cells to include the bipolar $\mathrm{A} 2 \mathrm{~B} 5{ }^{+}$cells $(\mathrm{O}-2 \mathrm{~A})$ and the multipolar $\mathrm{O}^{+}{ }^{+} \mathrm{GalC}^{-}$cells and the term differentiated OLGs to include $\mathrm{GalC}^{+}$cells. Figure 1 shows examples of immunofluorescence analysis of cultured OP cells and OLGs and their representative whole-cell currents. Macroscopic $\mathrm{K}^{+}$currents were recorded from cultured OP/OLGs, using the whole-cell configuration of the patch-clamp technique. $\mathrm{K}^{+}$currents in these cells have been characterized by various investigators (Sontheimer and Kettenmann, 1988; Soliven et al., 1989; Berger et al., 1991; Chvatal et al., 1995; Soliven and Wang, 1995) and will be described only briefly here. Pulses of $360 \mathrm{msec}$ were stepped to various voltages from a holding potential of $-80 \mathrm{mV}$ and from $-40 \mathrm{mV}$. Inward currents activated at hyperpolarized potentials were strongly dependent on external $\mathrm{K}^{+}$concentration and were sensitive to blockade by external $\mathrm{Ba}^{2+}$ and $\mathrm{Cs}^{+}$, as expected for $I_{\mathrm{Kir}}$. Outward $\mathrm{K}^{+}$currents (collectively referred to as $I_{\mathrm{Ko}}$ ) activated at depolarized potentials from a holding potential of $-40 \mathrm{mV}$ were noninactivating and exhibited either time-dependent activation resembling delayed rectifier $\left(I_{\mathrm{K}}\right)$ in some cells or time-independent $\left(I_{\mathrm{i}}\right)$ activation in others (Fig. 1). Whether $I_{\text {Ko }}$ contained a calcium- dependent component was not addressed in this study. An inactivating $\mathrm{K}^{+}$current resembling $I_{\mathrm{A}}$ was observed when voltage pulses were stepped from a holding potential of $-80 \mathrm{mV}$ (Fig. $1 B)$. The most common current profile exhibited by A2B5 ${ }^{+}$ bipolar cells consisted of $I_{\mathrm{K}}$ plus $I_{\mathrm{A}^{-}}$-like currents. Multipolar $\mathrm{O}^{+}$ cells could exhibit different ionic current patterns. Of the 29 multipolar cells studied, 10 of $29(34 \%)$ had $I_{\mathrm{K}}$ plus $I_{\mathrm{A}}, 8$ of 29 $(28 \%)$ had $I_{\mathrm{K}}$ plus $I_{\mathrm{A}}$ plus $I_{\mathrm{Kir}}, 5$ of $29(17 \%)$ had $I_{\mathrm{K}}$ plus $I_{\mathrm{Kir}}, 4$ of $29(14 \%)$ had $I_{\mathrm{K}}$ only, and 2 of $29(7 \%)$ had $I_{\mathrm{i}}$ plus $I_{\mathrm{Kir}}$. In contrast, 21 of $32(66 \%)$ highly arborized cells ( $\left.\mathrm{GalC}^{+} \mathrm{OLGs}\right)$ had $I_{\mathrm{i}}$ plus $I_{\mathrm{Kir}}, 10$ of $32(31 \%)$ had $I_{\mathrm{K}}$ plus $I_{\mathrm{Kir}}$, and only 1 of 32 $(3 \%)$ had $I_{\mathrm{K}}$ plus $I_{\mathrm{A}}$. Current recordings from cultured OLGs derived from P21 rat spinal cord were similar to those recorded from neonatal OLGs differentiated in vitro from OP cells (data not shown). Only $I_{\mathrm{K}}$ plus $I_{\mathrm{Kir}}$ or $I_{\mathrm{i}}$ plus $I_{\mathrm{Kir}}$ was observed in P21 OLGs (Soliven and Wang, 1995).

Because $I_{\mathrm{K}}$ was observed more frequently in OP cells than in OLGs, subsequent electrophysiological studies were performed in OP cells unless otherwise stated. To isolate $I_{\mathrm{K}}$ from $I_{\mathrm{A}}$, we recorded currents from a holding potential of $-40 \mathrm{mV}$. The threshold potential for activation of $I_{\mathrm{K}}$ was $-40 \mathrm{mV}$. The half-maximal activation voltage $\left(V_{1 / 2}\right)$ derived from fitting conductance-voltage plots to the Boltzmann function ranged from -14 to $-16 \mathrm{mV}(n=$ 4). As depicted in Figure $2, I_{\mathrm{K}}$ in OP cells was sensitive to inhibition induced by quinidine (Quin), 4-aminopyridine (4-AP), clofilium (clof), and tetraethylammonium (TEA). Peak $I_{\mathrm{K}}$ amplitude measured at $+60 \mathrm{mV}\left(V_{\mathrm{h}}=-40 \mathrm{mV}\right)$ was decreased to $24.8 \pm$ $4.3 \%(n=6)$ of its initial value by Quin $(50 \mu \mathrm{M})$, to $37 \pm 5.0 \%(n=$ 4) by $4-\mathrm{AP}(0.3 \mathrm{mM})$, to $31.3 \pm 6.9 \%(n=8)$ by clof $(0.5-1 \mu \mathrm{M})$, and to $58.2 \pm 4.3 \%(n=5)$ by external TEA $(2 \mathrm{mM})$. Thus the activation threshold and the pharmacological properties of $I_{\mathrm{K}}$ in OP cells resemble those described for the Kv1.5 channel or Kv1.6 channel, although the intermediate sensitivity to TEA and the $V_{1 / 2}$ would be more typical of cloned Kv1.6 than of a Kv1.5 channel (Swanson et al., 1990; Attali et al., 1993). 


\section{Molecular characterization of delayed rectifier $\mathrm{K}^{+}$ channels in OP cells and OLGs}

Potential caveats exist that complicate a direct comparison of biophysical and pharmacological properties of native channels with those of cloned channels expressed in oocytes. To identify the $\mathrm{Kv}$ genes that encode OP/OLG $I_{\mathrm{K}}$, we subjected total RNA extracts prepared from cultured OP cells [1 d in vitro (DIV)] and OLGs (5 DIV) to RT-PCR cloning, using degenerate oligonucleotides encoding the conserved domains of Shaker-related channel sequences (see Materials and Methods). The upstream primer corresponded to a conserved region NEYFFDR, located upstream of the first transmembrane domain S1. The downstream primer encoded the most conserved $\mathrm{H} 5$ pore signature sequence TTVGYG. A wide band of $\sim 950$ bp was amplified, gel-purified, subcloned, and sequenced. The sequencing data showed that previously known cDNAs encoding Kv1.2, Kv1.4, Kv1.5, and Kv1.6 channels have been picked up from OP cells and OLGs. Figure $3 B$ shows that indeed mRNAs encoding these Shakerrelated genes could be detected by RT-PCR with isoform-specific primers. Kv1.4 homomeric channels are known to produce a transient $I_{\mathrm{A}}$ current when expressed in Xenopus oocytes (Stühmer et al., 1989) and thus may represent the transient $I_{\mathrm{A}}$ current found mostly in $\mathrm{A} 2 \mathrm{~B}^{+}{ }^{+}$and $\mathrm{O} 4{ }^{+}$cells. Interestingly, Kv1.2, Kv1.5, and Kv1.6 channels produce noninactivating delayed rectifier $\mathrm{K}^{+}$ currents in expression systems (Stühmer et al., 1989; Pongs, 1992) and are good candidates for OP/OLG $I_{\mathrm{K}}$. Although Kv1.2 transcripts were not observed consistently by the RNase protection assay (data not shown), we could show that Kv1.5 and Kv1.6 mRNAs are expressed in cultured OP cells (1 DIV) and OLGs (8 DIV), as reflected by specific protected fragments of 342 and 475 base lengths, respectively (Fig. $3 A$ ). The levels of expression for both channels were significantly lower in differentiated OLGs when compared with OP cells. The Kv1.5 and Kv1.6 mRNA levels at 8 DIV corresponded to $35 \pm 15 \%$ and $55 \pm 10 \%$, respectively, of those detected at 1 DIV ( $p<0.01 ; n=5)$. In addition, the Kv1.5 mRNA levels were consistently higher than those of Kv1.6 transcripts. The decrease in Kv1.5 and Kv1.6 mRNAs during OLG differentiation in vitro also was correlated at the protein level (see Fig. 5C below). In situ hybridization with specific digoxigenin-labeled cRNA probes confirmed that $\mathrm{Kv} 1.5$ and Kv1.6 transcripts were expressed by multipolar $\mathrm{O}^{+}{ }^{+} \mathrm{GalC}^{-} \mathrm{OP}$ cells (Fig. 4E,F) and by complex process-bearing $\mathrm{GalC}^{+} \mathrm{MBP}^{+}$ OLGs in vitro (Fig. $4 A-D$ ). No obvious difference in the spatial distribution of Kv1.5 versus Kv1.6 transcripts was detected.

The expression of Kv1.5 and Kv1.6 channels was confirmed at the protein level by Western blot analysis or immunocytochemistry, using affinity-purified polyclonal antibodies (Figs. 5, 6). To obtain isoform specific antisera, we raised the antibodies in rabbits against a specific $\mathrm{C}$-terminal region downstream of the S6 transmembrane segment of the various Kv channels. The antigens were generated as fusion proteins with GST (see Materials and Methods). The specificity of these antibodies was verified by using HEK 293 cells transfected with either Kv1.5 or Kv1.6 cDNAs both by Western blot analysis and immunofluorescence studies (Fig. 5A,B). Western blots of lysates from transfected HEK 293 cells showed immunoreactive bands of $\sim 78$ and $80 \mathrm{kDa}$ for Kv1.5 and Kv1.6 channel proteins, respectively. These immunoreactive bands were absent in untransfected cells (Fig. 5A). Western blots of total brain lysates also revealed immunoreactivity to both Kv1.5 and Kv1.6 proteins, and preadsorption of the antibodies
A
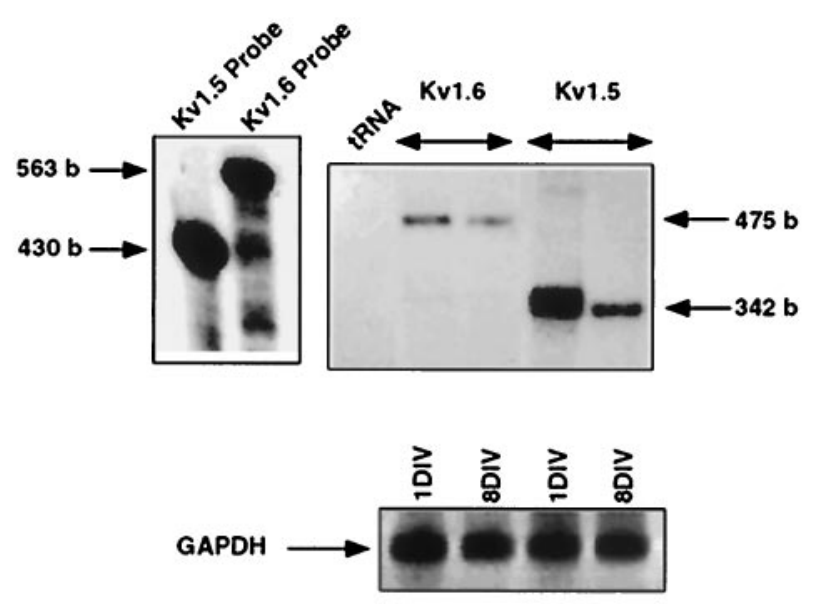

B

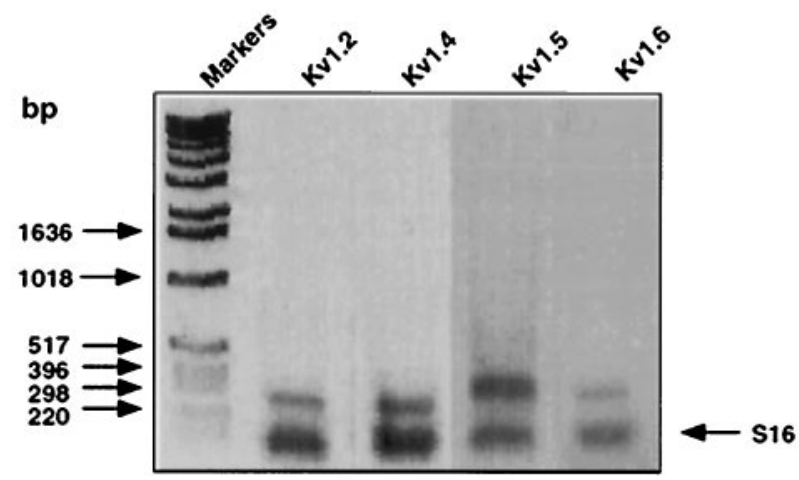

Figure 3. RNase protection analysis $(A)$ and RT-PCR identification of voltage-gated $\mathrm{K}^{+}$channel transcripts in OP cells and OLGs $(B)$. $A$, Total RNA was prepared from primary cultures of OP cells and OLGs grown in Sato 1 medium for 1 and $8 \mathrm{~d}$ in vitro ( $1 D I V$ and $8 D I V$, respectively) and hybridized with [ $\left.{ }^{32} \mathrm{P}\right] \mathrm{UTP}$-labeled antisense cRNA probes (see Materials and Methods). Yeast tRNA was used as a control for hybridization specificity, and GAPDH hybridization signal was used for a semiquantitative estimation of the total RNA input in each extract. The sizes of the probes and of the protected fragments are indicated by arrows. B, RTPCR amplification using primer pairs to the specific $3^{\prime}$ coding regions of the respective Kv channels, followed by Southern blot analysis (see Materials and Methods). The sizes of Kv1.2, Kv1.4, Kv1.5, and Kv1.6 PCR fragments were 248, 204, 273, and 206 bp, respectively. The bottom band represents the S16 ribosomal protein PCR fragment (102 bp), which is used for a semiquantitative estimation of the starting input RNA.

with their respective antigens blocked the signal on the blots (data not shown).

We found that Kv1.5 and Kv1.6 channel proteins were expressed by cultured OP cells and OLGs. Figure $5 C$ shows that the Kv1.5 and Kv1.6 antibodies recognized immunoreactive proteins of 90 and $88 \mathrm{kDa}$ molecular weight, respectively, in Western blots of lysates from OP cells and OLGs. In differentiated OLGs the expression of both channels at the protein level was significantly lower than that found in OP cells (Fig. 5C). The Kv1.5 and Kv1.6 immunoreactive protein levels at 8 DIV corresponded to $49 \pm$ $12 \%$ and $42 \pm 15 \%$, respectively, of those detected at 1 DIV $(p<$ $0.05 ; n=4)$. The apparent molecular weight of Kv1.5 and Kv1.6 channel proteins was higher than that predicted from cDNA sequences. This is probably attributable to extensive post- 

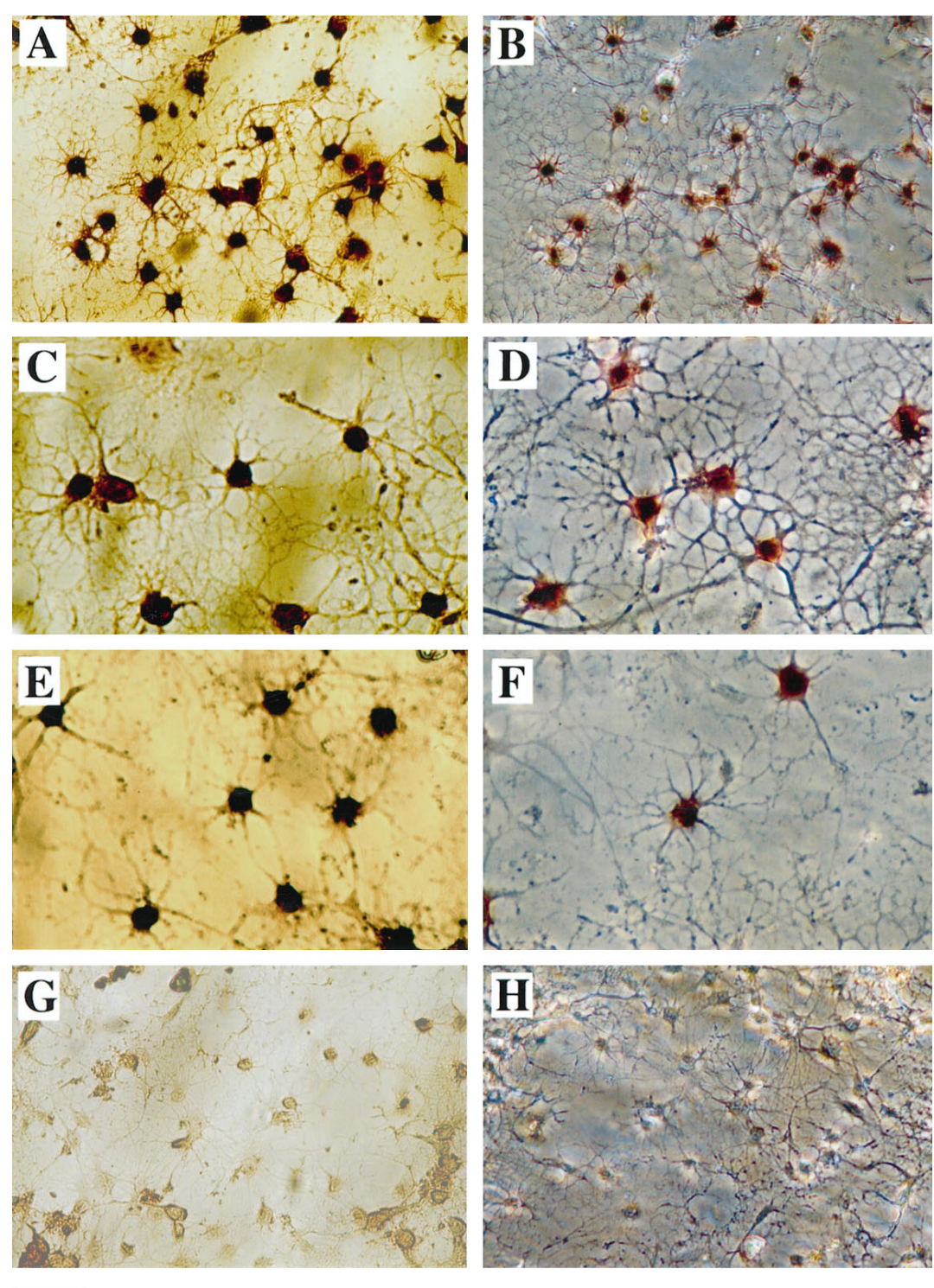

Figure 4. Detection of Kv1.5 and Kv1.6 transcripts by in situ hybridization in OP cells and OLGs with digoxigeninlabeled cRNA probes. Hybridization to Kv1.5 (left) and Kv1.6 (right) with antisense riboprobes is shown in $A, C$, and $E$ and in $B, D$, and $F$, respectively. Hybridization to $\mathrm{Kv} 1.5$ and Kv1.6 sense riboprobes is shown in $G$ and $H$, respectively. Cells are OLGs $\left(\mathrm{MBP}^{+}, 8 \mathrm{DIV}\right)$ except in $E$ and $F$, where multipolar OP cells $\left(\mathrm{O}^{+}, 2 \mathrm{DIV}\right)$ are shown. Scale bars: $A, B, G, H, 70 \mu \mathrm{m} ; C-F, 40 \mu \mathrm{m}$. translational modifications such as glycosylation and/or phosphorylation. The same phenomenon was observed for other Kv channel subunits in the brain (Scott et al., 1994; Veh et al., 1995) and even for glial cells (Mi et al., 1995, 1996). The different molecular weight found for Kv1.5 and Kv1.6 isoforms in OLGs and transfected HEK 293 cells also may reflect a difference in the extent of such post-translational modifications. In Figure 6, immunocytochemical analysis shows that both channel proteins are expressed in $\mathrm{A} 2 \mathrm{~B} 5{ }^{+} \mathrm{OP}$ cells $(1 \mathrm{DIV})$ and in differentiated GalC ${ }^{+}$OLGs $(5$ DIV). There was no difference in the spatial localization of Kv1.5 and Kv1.6 proteins in OLGs, although the reactivity for Kv1.6 antibody in the processes appeared to be stronger than that observed for Kv1.5 antibody.

Using affinity-purified antibodies (Alomone Labs), we could detect by Western blot analysis the expression of Kv1.2 and Kv1.4 immunoreactive channel proteins in OLGs (Fig. 5C). Kv1.2 and Kv1.4 antibodies recognized immunoreactive proteins of 75 and $115 \mathrm{kDa}$ molecular weight, respectively, for which the values are close to those found in brain extracts (Scott et al., 1994; Veh et al., 1995). Figure $5 C$ also shows that preadsorption of the antibodies with their respective antigens and not with GST alone blocked the immunoreactivity on the blots.

\section{Kv1.5 channel is the major component underlying $I_{K}$ in OP cells and OLGs}

Our electrophysiological studies suggest that $I_{\mathrm{K}}$ in OP cells may be encoded by Kv1.5 or Kv1.6 channel subunits. To test the above hypothesis, we studied the effect of phosphorothioate antisense ODNs specific for Kv1.5 and Kv1.6 cDNA sequences on $I_{\mathrm{K}}$ recorded from OP cells. The effectiveness of $24 \mathrm{hr}$ treatment of the cells with antisense ODNs $(1 \mu \mathrm{M})$ in downregulating the expression of Kv1.5 and Kv1.6 mRNAs and proteins was examined by RT-PCR or RNase protection analysis as well as by Western blotting (Fig. 7). When compared with sense ODN treatment (ODN19, ODN20) or with untreated control cells, antisense ODN exposure (ODN4, ODN21) led to $58 \pm 23 \%$ and $85 \pm 10 \%$ downregulation of Kv1.5 and Kv1.6 mRNA levels, respectively, as measured by RNase protection $(p<0.05 ; n=4)$. Similar results were obtained by semiquantitative RT-PCR (60 \pm $20 \%$ and $90 \pm 18 \%$ downregulation of Kv1.5 and Kv1.6 mRNA levels, respectively, when compared with untreated cells or with sense ODN; $p<0.01 ; n=5)$. Figure $7 D$ similarly showed that a strong reduction in Kv1.5 and Kv1.6 immunoreactive protein levels was obtained after antisense ODN treatment, as measured 
A

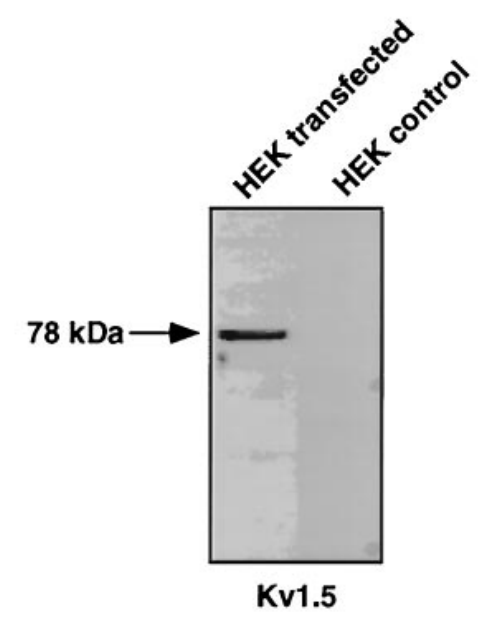

B

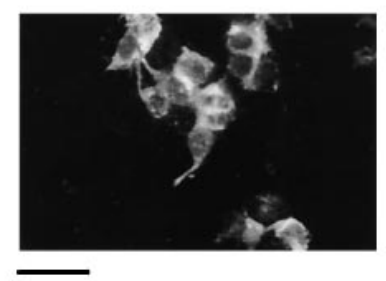

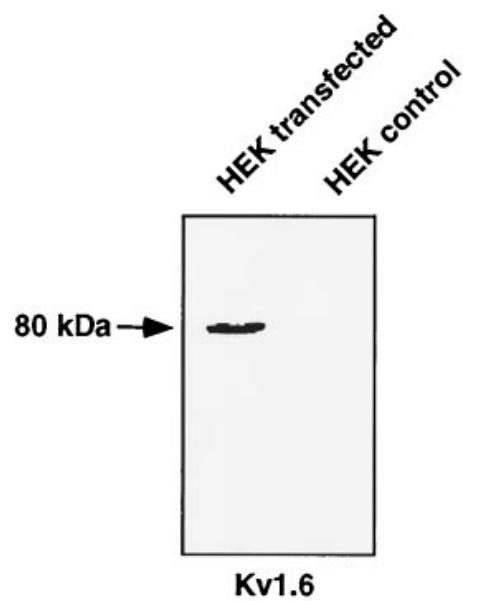

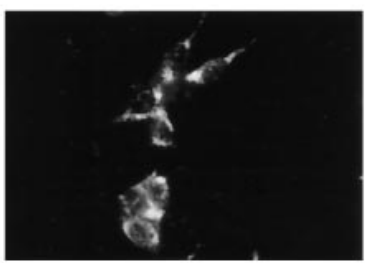

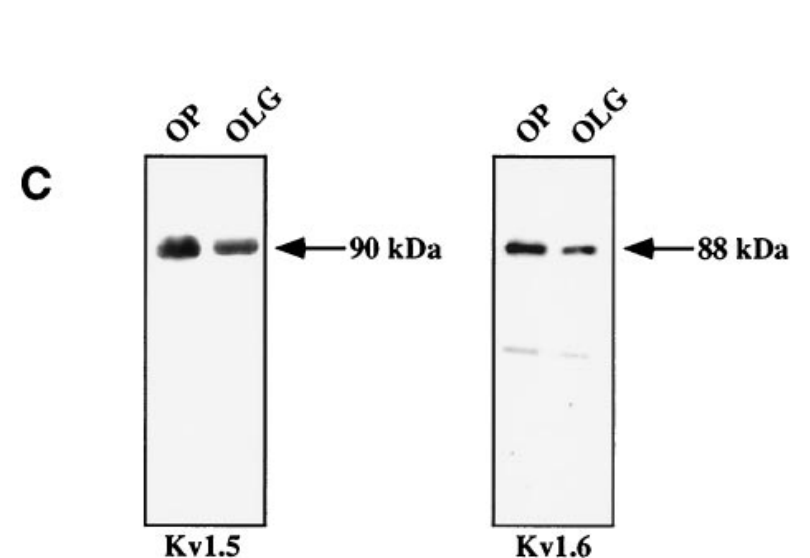
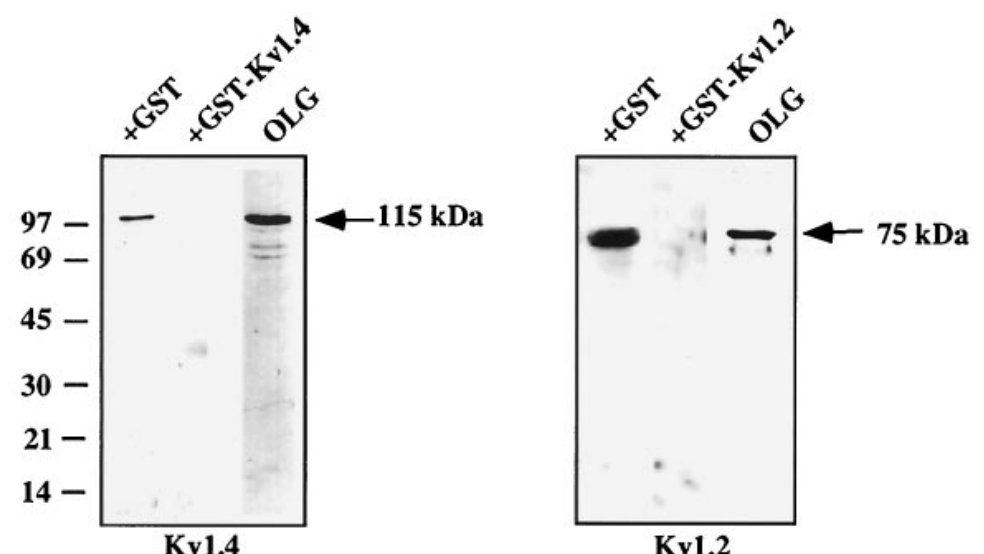

Figure 5. Immunodetection of Kv1.2, Kv1.4, Kv1.5, and Kv1.6 channel proteins in OP cells/OLGs. $A$, $B$, Specificity of anti-Kv1.5 and anti-Kv1.6 polyclonal antibodies in transfected HEK 293 cells. Shown are Western blots of extracts from HEK 293 cells transfected with Kv1.5 or Kv1.6 cDNAs or with the control plasmid, using anti-Kv1.5 and anti-Kv1.6 polyclonal antibodies $(A)$. Also shown are immunofluorescence micrographs (FITC) of HEK 293 cells transfected with Kv1.5 or Kv1.6 cDNAs and incubated with the anti-Kv1.5 (left) or anti-Kv1.6 (right) polyclonal antibodies (B). Scale bar, 70 $\mu \mathrm{m}$. $C$, Western blots of OP (1 DIV) or OLG (8 DIV) lysates probed with anti-Kv1.2, anti-Kv1.4, anti-Kv1.5, and anti-Kv1.6 polyclonal antibodies. When indicated, anti-Kv1.2 and anti-Kv1.4 antibodies were preadsorbed with their respective recombinant channel-GST fusion proteins or GST alone to check for specificity.

by Western blotting $(45 \pm 18 \%$ and $70 \pm 25 \%$ downregulation of Kv1.5 and Kv1.6 protein levels, respectively, as compared with sense ODN; $p<0.05 ; n=5$ ). No reduction in Kv1.5 protein levels could be observed after Kv1.6 antisense ODN treatment and vice versa (data not shown). These results showed that the phosphorothioate antisense ODNs were effective and specific and could reduce by at least $45 \%$ the respective channel protein levels.

For electrophysiological studies, sense and antisense ODNs were added directly to cultured OP cells (1-2 DIV) under serumfree conditions without ITS for $24 \mathrm{hr}$. Recordings from both bipolar and multipolar progenitors were included in the analysis so that the predominating current was not $I_{\mathrm{Kir}}$ nor the time- independent current. Holding potential was $-40 \mathrm{mV}$. Peak current amplitudes were measured at $0 \mathrm{mV}$ to avoid possible contamination with $\mathrm{Cl}^{-}$currents, which had a reversal potential close to $0 \mathrm{mV}$ under our experimental conditions. Figure 8 shows the summarized data on $I_{\mathrm{K}}$ current densities. The incubation of OP cells for $24 \mathrm{hr}$ with Kv1.5 antisense ODN18 (1-2 $\mu \mathrm{M})$ and ODN4 $(1-2 \mu \mathrm{M})$ in serum-free condition (SFM) resulted in a decrease in $I_{\mathrm{K}}$ current density, whereas incubation for $24 \mathrm{hr}$ with Kv1.5 sense ODN16 $(1-2 \mu \mathrm{M})$ had no effect on $I_{\mathrm{K}}$ current density. $I_{\mathrm{K}}$ current density was $34.1 \pm 2.8 \mathrm{pA} / \mathrm{pF}(n=19)$ in cells incubated in SFM, $23.4 \pm 2.1 \mathrm{pA} / \mathrm{pF}(n=21)$ in cells incubated with ODN4, $20.8 \pm$ $2.8 \mathrm{pA} / \mathrm{pF}(n=13)$ in cells incubated with ODN18, and $43.3 \pm 7.9$ $\mathrm{pA} / \mathrm{pF}(n=15)$ in cells treated with ODN16 $(p<0.002$ for 

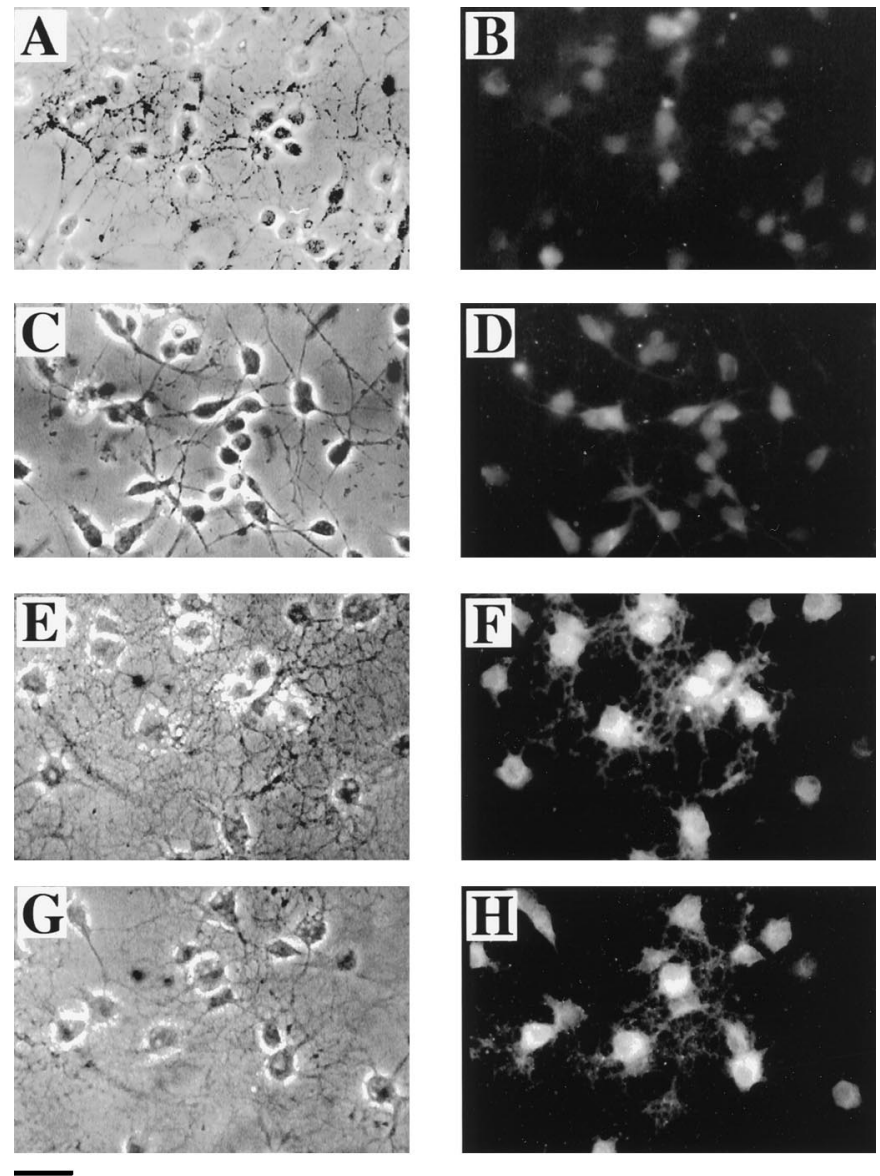

Figure 6. Immunofluorescence studies of OP cells and OLGs incubated with anti-Kv1.5 and anti-Kv1.6 antibodies. Shown are phase-contrast and corresponding immunofluorescence micrographs (FITC) of OP cells (A2B5 $\left.{ }^{+}, 1 \mathrm{DIV}\right)$ and of OLGs $\left(\mathrm{GalC}^{+}, 5 \mathrm{DIV}\right)$ incubated with anti-Kv1.5 $(C, D, G, H)$ or anti-Kv1.6 polyclonal antibodies $(A, B, E, F)$. Scale bar, $50 \mu \mathrm{m}$.

overall ANOVA, for SFM vs ODN4, and for SFM vs ODN18; $p>$ 0.05 for SFM vs ODN16).

It is known that $I_{\mathrm{K}}$ is observed less frequently in differentiated OLGs than in OP cells. Because we found that Kv1.5 and Kv1.6 channel transcripts and protein levels were decreased but not totally suppressed in differentiated OLGs (5-8 DIV) from neonatal brain (see Figs. 3-5) or P21 brain (data not shown), we examined whether the Kv1.5 channel subunit contributes to outward $\mathrm{K}^{+}$currents in P21 OLGs (Fig. 8). The holding potential was -80 instead of $-40 \mathrm{mV}$, because $I_{\mathrm{A}}$ was rarely observed in recordings from P21 OLGs. $I_{\mathrm{K}}$ current density in P21 OLGs was $38.4 \pm 6.1 \mathrm{pA} / \mathrm{pF}(n=23)$ for cells in SFM, $23.3 \pm 3.1 \mathrm{pA} / \mathrm{pF}$ $(n=18)$ for cells treated with antisense ODN4, $19.9 \pm 3.3 \mathrm{pA} / \mathrm{pF}$ $(n=15)$ for cells treated with antisense ODN18, $42.8 \pm 8.2$ $\mathrm{pA} / \mathrm{pF}(n=20)$ for cells treated with sense ODN16, and $32.3 \pm$ $6.2 \mathrm{pA} / \mathrm{pF}(n=18)$ for cells treated with sense ODN19 (Fig. 8). The $p$ value for the above data was $<0.04$ for overall ANOVA, with $p<0.001$ for SFM versus ODN18 or ODN4, but $p>0.05$ for SFM versus ODN16 or ODN19. We also examined whether resting membrane potential (RMP) and total membrane capacitance differed between untreated OLGs and ODN-treated OLGs. There was no significant difference in the RMP of untreated OLGs and OLGs treated with either Kv1.5 sense or antisense
ODNs. Total membrane capacitance also did not differ between control OLGs and ODN-treated OLGs (data not shown). These results confirm that at least a component of outward $\mathrm{K}^{+}$currents in OLGs is attributable to activation of Kv1.5 channel. Although Kv1.6 transcript and protein were detected in cells of OLG lineage by RNase protection analysis and Western blotting, respectively, incubation of OP cells and OLGs with Kv1.6 antisense ODN did not result in a significant decrease in $\mathrm{K}^{+}$current amplitudes (data not shown). Note that $1 \mu \mathrm{M}$ Kv1.6 antisense ODN was effective in downregulating Kv1.6 mRNA and protein levels (Fig. 7A,C,D); thus its inability to decrease $I_{\mathrm{K}}$ density does not appear to be attributable to technical problems.

\section{Role of $\boldsymbol{I}_{\mathrm{K}}$ in mitogenesis of OP cells}

To determine the relevance of $I_{\mathrm{K}}$ to OP proliferation, we examined whether inhibition of $I_{\mathrm{K}}$ by $\mathrm{K}^{+}$channel blockers or by antisense ODNs blocks OP mitogenesis. Both PDGF and bFGF are known to stimulate the proliferation of OP cells (Gard and Pfeiffer, 1993). As expected, the addition of PDGF and bFGF (Sato 2 medium) to OP stimulated $\left[{ }^{3} \mathrm{H}\right]$ thymidine incorporation by $3.7 \pm 0.2$-fold when compared with untreated cultures in Sato 1 medium (Fig. $9 A ; p<$ $0.01 ; n=5)$. This effect was not attenuated by the presence of Kv1.5 or Kv1.6 antisense or sense ODNs ( $1 \mu \mathrm{M}$ ODN4 and ODN21 or ODN19 and ODN20, respectively) in Sato 2 medium (Fig. 9A), yet the same Kv1.5 and Kv1.6 antisense ODNs (ODN4 and ODN21, respectively) inhibited Schwann cell proliferation (A. Kolot, A. Sobko, O. Shirihai, D. Dagan, and B. Attali, unpublished results). Interestingly the $\left[{ }^{3} \mathrm{H}\right]$ thymidine incorporation in OP cells was inhibited significantly with the addition of $100 \mu \mathrm{M}$ Quin, 500 $\mu \mathrm{M}$ quinine, $10 \mu \mathrm{M}$ clof, or $3 \mathrm{~mm} 4-\mathrm{AP}$ by $79.7 \pm 7.4 \%, 97.9 \pm 0.5 \%$, $70.0 \pm 3.6 \%$, and $65.7 \pm 4.5 \%$, respectively (Fig. $9 B ; p<0.01$; $n=5)$.

\section{DISCUSSION}

This study has demonstrated the presence of multiple Kv transcripts and proteins in cells of OLG lineage. Our findings indicate that $\mathrm{Kv1} 1.2, \mathrm{Kv1.4}, \mathrm{Kv1.5}$, and Kv1.6 channel mRNAs and proteins are expressed by these cells, although definitive evidence for functional $\mathrm{K}^{+}$channel expression was obtained only for Kv1.5 channels. Kv1.5 and Kv1.6 antisense ODNs did not inhibit proliferation of $\mathrm{OP}$ cells, but $\mathrm{K}^{+}$channel blockers known to inhibit either channel attenuated OP proliferation stimulated by PDGF and bFGF. Perhaps concomitant inhibition of other Kv channels underlying $I_{\mathrm{K}}$ is necessary to block OP proliferation.

Both Kv1.5 and Kv1.6 channel proteins could be detected in OP cells and OLGs by Western blot analysis and immunofluorescence studies. However, successful but partial inhibition of $I_{\mathrm{K}}$ expression with antisense ODN could be demonstrated only for Kv1.5, although inhibition was seen for both Kv1.5 and Kv1.6 antisense ODNs by RNase protection and Western blot analysis. One possible explanation for this apparent discrepancy would be that Kv1.6 does not form functional $\mathrm{K}^{+}$channels in OP cells/ OLGs, although protein expression can be detected. Alternatively, OP/OLG $I_{\mathrm{K}}$ may result from coassembly of Kv1.5, Kv1.6, and possibly Kv1.2 subunits, with a stoichiometry in favor of $\mathrm{Kv1.5}$; the latter can substitute for the other subunits in their absence. This argument is supported by our finding that the level of expression of Kv1.5 transcript and protein appears to be significantly higher than that observed for Kv1.6. Coassembly of Shaker-like subunits into heteromultimeric channels has been demonstrated not only in the Xenopus oocyte expression system (Isacoff et al., 1990; Ruppersberg et al., 1990) but also in vivo in 


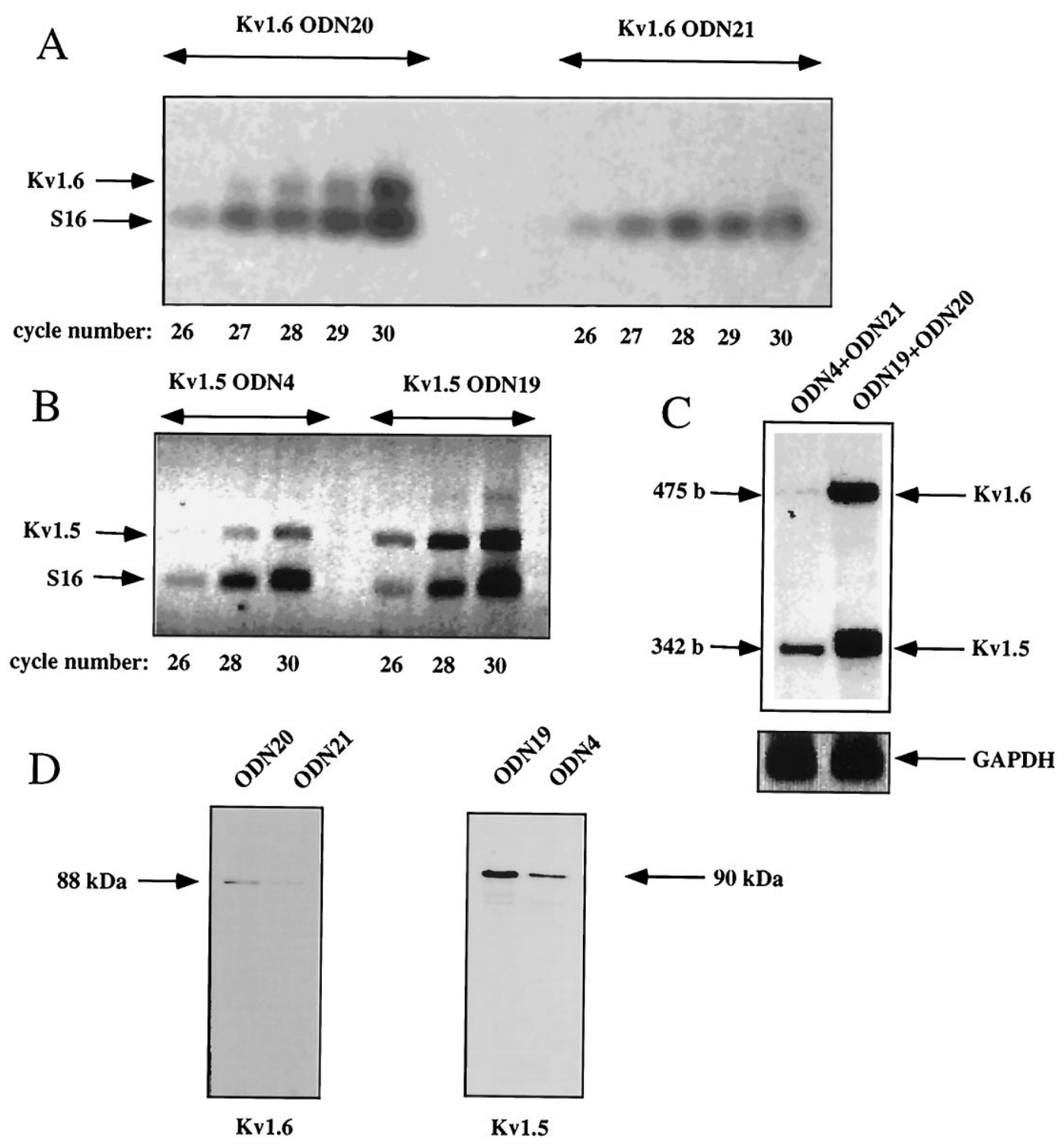

Figure 7. Effect of antisense oligonucleotides on expression of Kv1.5 and Kv1.6 mRNA and protein levels in OLGs (5 DIV). Shown are semiquantitative RT-PCR identification $(A, B)$ and RNase protection analysis $(C)$ of Kv1.5 and Kv1.6 channel transcripts in OLG cultures after $24 \mathrm{hr}$ of treatment with a $1 \mu \mathrm{M}$ concentration of the sense (ODN19 and ODN20, respectively) and antisense phosphorothioate ODNs (ODN4 and ODN21, respectively). In RNase protection analysis $(C)$, the Kv1.5 and Kv1.6 sense $(O D N 19+O D N 20)$ or antisense ODNs $(O D N 4+O D N 21)$ were added simultaneously to the cells. $D$, Western blot analysis of OLG lysates treated as above and probed with rabbit anti-Kv1.5 or anti-Kv1.6 polyclonal antibodies. Blots were developed by using the ECL detection method.

terminal and juxtaparanodal regions of neurons (Sheng et al., 1993; Wang et al., 1993).

There are potential caveats in a direct comparison between electrophysiological data and other protein detection methods such as Western blot analysis and immunofluorescence studies. First, the sensitivity of electrophysiological recording as an assay to detect the disruption of gene expression/translation by antisense ODNs may be attenuated when multiple channel subunits exhibiting similar activation and inactivation parameters contribute to the macroscopic current. Second, a differential spatial distribution of $\mathrm{K}^{+}$channels (i.e., soma vs processes) also would result in variable accessibility of subcellular compartments to electrophysiological recording. Mi et al. (1995) have demonstrated the preferential localization of Kv1.5 and Kv1.1 on the Schwann cell membrane at the nodes of Ranvier and in the axonal membrane at juxtaparanodal regions, respectively, in rat sciatic nerves, although both can be seen in the perinuclear intracellular compartments of Schwann cells. Similarly, striking differences in spatial localization have been observed for Kv2.1 and Kv2.2 (Hwang et al., 1993). In our study the failure to detect the inhibition of OP/OLG $I_{\mathrm{K}}$ by antisense Kv1.6 ODN cannot be explained on the basis of segregation of Kv1.6 to extrasomal regions.

The native OP/OLG $I_{\mathrm{K}}$ characteristics correlate quite well with those described for the Kv1.5 channel except for its $V_{1 / 2}$ values and intermediate TEA sensitivity, a finding that is in agreement with the results of other investigators (Gallo et al., 1996). Cloned Kv1.5 is not very sensitive to blockade by external TEA, although slight inhibition can be seen at high concentrations (Grissmer et al., 1994). A similar discrepancy in pharmacological properties 


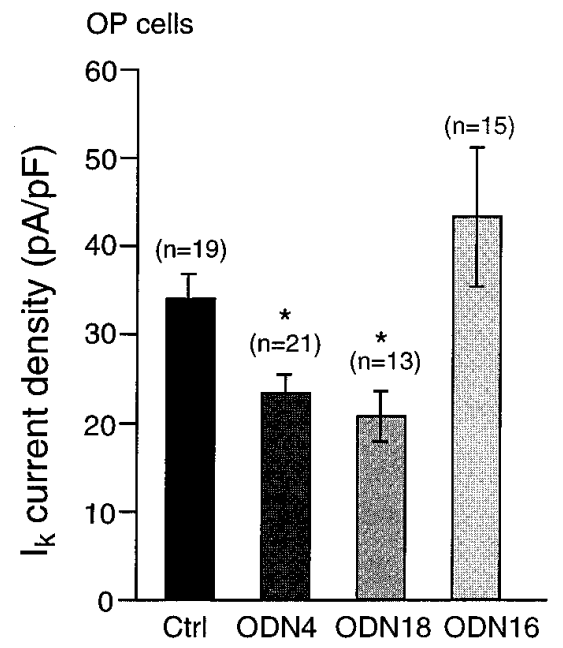

P21 OLGs

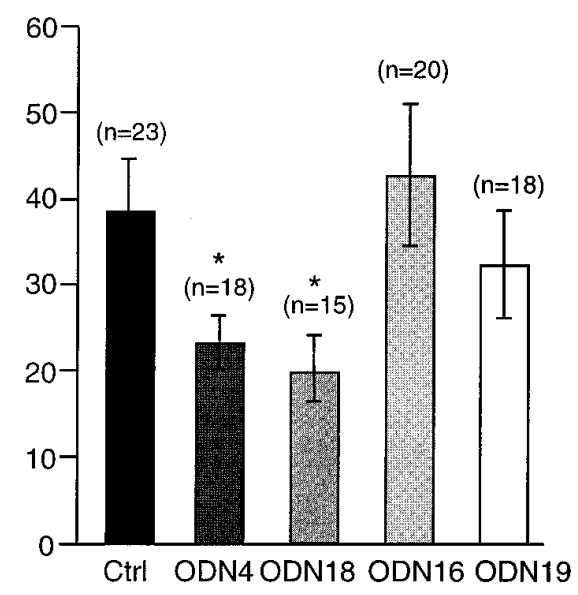

Figure 8. Effect of antisense oligonucleotides on OP/ OLG $I_{\mathrm{K}}$ current density. Summarized data show the inhibitory effect of Kv1.5 antisense ODNs (ODN4, ODN18), but not sense ODNs (ODN16, ODN19), on $I_{\mathrm{K}}$ current density in OP cells (left panel) and in P21 OLGs (right panel). Kv1.6 sense and antisense ODNs had no effect on $I_{\mathrm{K}}$ density (data not shown). Cells were treated with 1-2 $\mu \mathrm{M}$ ODNs for $24 \mathrm{hr}$ before electrophysiological recordings. Peak current amplitudes were measured at $0 \mathrm{mV}$. Holding potential was $-40 \mathrm{mV}$ in OP cells and $-80 \mathrm{mV}$ in P21 OLGs. ${ }^{*} p<$ 0.002 for $C t r l$ versus ODN4 or ODN18. between native Schwann cell $I_{\mathrm{K}}$ and cloned Kv1.5 has been observed and attributed to a difference in cellular milieu, the possible presence of $\beta$-subunit in native cells, or post-translational modification (Mi et al., 1995). If Kv1.5 coassembles with Kv1.6 to form a heterotetramer in OLGs, perhaps the presence of a single Kv1.6 subunit would be sufficient to confer a substantial sensitivity to external TEA, as described for charybdotoxin-induced blockade of $\mathrm{K}^{+}$channels (MacKinnon, 1991). Alternatively, TEA sensitivity could be explained by the presence of an apaminsensitive $\mathrm{Ca}^{2+}$-activated $\mathrm{K}^{+}$conductance that has been described in OP cells (Sontheimer et al., 1989). In astrocytes, Kv1.5 channel protein also contributes substantially to $I_{\mathrm{K}}$; its sensitivity to TEA increases after treatment with antisense ODN to Kv1.5, suggesting that the homo- or heteromultimeric channels remaining after antisense treatment differ from Kv1.5 in their external binding sites for TEA (Roy et al., 1996).

We found that $\left[{ }^{3} \mathrm{H}\right]$ thymidine incorporation was decreased by $I_{\mathrm{K}}$ channel blockers, suggesting that $I_{\mathrm{K}}$ plays an important role in OP proliferation, yet antisense Kv1.5 or Kv1.6 ODNs failed to inhibit proliferation stimulated by mitogens in our study. Possible explanations for the above discrepancy include any of the following: (1) exposure for $24 \mathrm{hr}$ to antisense ODNs $(1 \mu \mathrm{M})$ might be sufficient to inhibit $\mathrm{Kv}$ gene expression and translation under baseline conditions (i.e., in the absence of mitogens), but perhaps not under stimulated conditions (i.e., in the presence of mitogens); (2) concomitant blockade of other Kv channels such as Kv1.2 or Kv1.4 might be required to inhibit mitogen-stimulated proliferation of OP cells. The latter is a plausible scenario, given the overlapping actions of $\mathrm{K}^{+}$channel blockers on various $\mathrm{Kv}$ channel subtypes.

That glial $\mathrm{K}^{+}$channels may be linked to cellular proliferation is supported by studies of other investigators (Chiu and Wilson, 1989; Sontheimer, 1994; Gallo et al., 1996). $\mathrm{K}^{+}$channel blockers have been shown to inhibit mitogenesis in Schwann cells (Chiu and Wilson, 1989). In addition, growth factors that act as mitogens increase the expression of $\mathrm{K}^{+}$channels in these cells (Wilson and Chiu, 1993). Inhibition of OP proliferation by activation of AMPA glutamate receptors was mediated via inhibition of $I_{\mathrm{K}}$ (Gallo et al., 1996). How does the blockade of $I_{\mathrm{K}}$ lead to antiproliferative effects? Knutson et al. (1997) found that depolarization with high $\mathrm{K}^{+}$alone is sufficient to inhibit OP proliferation, although the absence of antiproliferative response to high $\mathrm{K}^{+}$ also has been reported (Barres and Raff, 1993). A mechanism involving $\mathrm{K}^{+}$channels in volume regulation during mitogenesis has been proposed (Dubois and Rouzaire-Dubois, 1993). In mitogen-stimulated cells the increased cell size because of the uptake of nutrients could be compensated by a regulatory volume decrease, which depends on coactivation of $\mathrm{K}^{+}$channels. Data from astrocytes suggest that $\mathrm{K}^{+}$channel blockers inhibit the proliferation of glial cells via changes in internal $\mathrm{pH}$ (Pappas et al., 1994). Although the precise mechanisms by which $\mathrm{K}^{+}$channels modulate proliferation remain unclear, there is increasing evidence that they might be involved in regulating the $\mathrm{G} 1$ to $\mathrm{S}$ transition of the cell cycle (Nilius and Droogmans, 1994). Aside from $\mathrm{K}^{+}$channels, electrical activity in axons also influence the proliferation of OP cells. Injection of tetrodotoxin into one eye of P15 rats results in a decreased number of mitotic glial cells in the developing nerve (Barres and Raff, 1993).

Early events in myelination consist of the proliferation of progenitor cells, followed by differentiation into OLGs and the synthesis of myelin components. This process is associated with tightly controlled expression of a $\mathrm{K}^{+}$channel repertoire, which may reflect the specialized function of individual channel subtypes at different stages of myelinogenesis. Our results and those of others support the concept that $I_{\mathrm{K}}$ is important for the regulation of OP proliferation. Prolonged exposure to TEA eliminated myelination without affecting axonal growth and conduction in spinal cord explants (Shrager and Novakovic, 1995). During OLG differentiation the inward rectifier becomes the predominant current. We have shown previously that inhibition of inward rectifier leads to membrane depolarization and a decrease in phosphorylation of myelin proteins (Soliven et al., 1994). Post-translational modifications of myelin proteins potentially can alter the structure of and interactions within myelin membranes (Moscarello, 1990). Once myelination is completed, the inward rectifier continues to play an important role, this time in the control of $\mathrm{K}^{+}$homeostasis in the CNS (Barres et al., 1990; Hertz et al., 1990). Therefore, modulation of $\mathrm{K}^{+}$channel expression or function in OP cells/OLGs is likely to affect either the initiation of myelinogenesis or myelin maintenance. We conclude that (1) Kv1.5 is a major but not exclusive component of OP/OLG $I_{\mathrm{K}}$, possibly forming a heteromultimeric channel with Kv1.6 or Kv1.2 channels; and (2) inhibition of Kv1.5 or Kv1.6 channel expression alone does not prevent mitogenesis. Perhaps concomitant inhibition of other $\mathrm{Kv}$ channels underlying $I_{\mathrm{K}}$ is necessary for OP cells to exit from the cell cycle. 

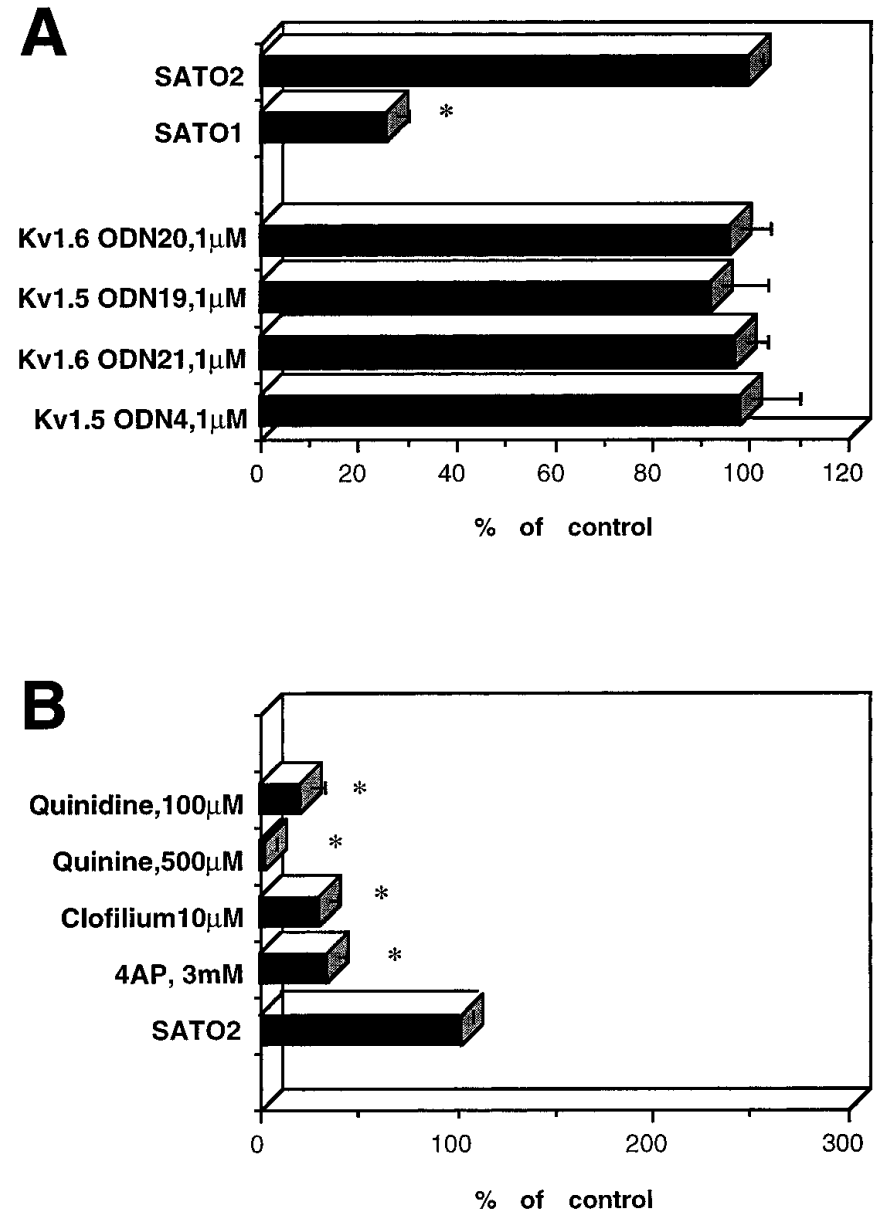

Figure 9. Effect of $\mathrm{K}^{+}$channel blockers and of Kv1.5 or Kv1.6 antisense ODNs on OP proliferation. A, Kv1.5 and Kv1.6 sense (ODN19, ODN20) or antisense $(O D N 4, O D N 21)$ phosphorothioate ODNs were added for 24 $\mathrm{hr}$, and then $\left[{ }^{3} \mathrm{H}\right]$ thymidine $(0.2 \mu \mathrm{Ci} /$ well $)$ was added for another $24 \mathrm{hr}$ (see Materials and Methods). The results were expressed as a percentage of control proliferation in Sato 2 medium, which contained both PDGF and bFGF at $5 \mathrm{ng} / \mathrm{ml}$ each. Sato 1 medium is serum-free defined medium. $B$, The results were expressed as a percentage of maximal mitogenstimulated proliferation, measured by the difference between $\left[{ }^{3} \mathrm{H}\right]$ thymidine incorporation in cells grown in Sato 2 medium and that obtained from cells in Sato 1 medium. Each data point represents the mean \pm SEM of five independent experiments, each performed in triplicate. ${ }^{*} p<0.01$ with Student's $t$ test.

\section{REFERENCES}

Attali B, Lesage F, Ziliani P, Guillemare E, Honore E, Waldman R, Hugnot JP, Mattei MG, Lazdunski M, Barhanin J (1993) Multiple mRNA isoforms encoding the mouse cardiac Kv1-5 delayed rectifier $\mathrm{K}^{+}$channel. J Biol Chem 268:24283-24289.

Barres BA, Raff MC (1993) Proliferation of oligodendrocyte precursor cells depends on electrical activity in axons. Nature 361:258-260.

Barres BA, Koroshetz WJ, Swartz KJ, Chun LLY, Corey DP (1990) Ion channel expression by white matter glia: the O-2A glial progenitor cell. Neuron 4:507-524.

Berger T, Schnitzer J, Kettenmann H (1991) Developmental changes in the membrane current pattern, $\mathrm{K}^{+}$buffer capacity, and morphology of glial cells in the corpus callosum slice. J Neurosci 11:3008-3024.

Chiu SY, Wilson GF (1989) The role of potassium channels in Schwann cell proliferation in Wallerian degeneration of explant rabbit sciatic nerves. J Physiol (Lond) 408:199-222.

Chiu SY, Scherer SS, Blonski M, Kang SS, Messing A (1994) Axons regulate the expression of Shaker-like potassium channel genes in Schwann cells in peripheral nerves. Glia 12:1-11.

Chomczynski P, Sacchi N (1987) Single-step method of RNA isolation by acid guanidinium thiocyanate-phenol-chloroform extraction. Anal Biochem 162:156-159.

Chvatal A, Pastor A, Mauch M, Sykova E, Kettenmann H (1995) Distinct populations of identified glial cells in the developing rat spinal cord slice: ion channel properties and cell morphology. Eur J Neurosci 7:129-142.

Doupnik CA, Davidson N, Lester HA (1995) The inward rectifier potassium channel family. Curr Opin Neurobiol 5:268-277.

Dubois JM, Rouzaire-Dubois B (1993) Role of potassium channels in mitogenesis. Prog Biophys Mol Biol 59:1-21.

Dubois-Dalcq M (1987) Characterization of a slowly proliferative cell along the oligodendrocyte differentiation pathway. EMBO J 6:2587-2595.

Gallo V, Zhou JM, McBain CJ, Wright P, Knutson PL, Armstrong RC (1996) Oligodendrocyte progenitor cell proliferation and lineage progression are regulated by glutamate receptor-mediated $\mathrm{K}^{+}$channel block. J Neurosci 16:2659-2670.

Gard AL, Pfeiffer SE (1989) Oligodendrocyte progenitors isolated directly from developing telencephalon at a specific phenotypic stage: myelinogenic potential in a defined environment. Dev Biol 106:119-132.

Gard AL, Pfeiffer SE (1993) Glial cell mitogens bFGF and PDGF differentially regulate development of $\mathrm{O}^{+}{ }^{+} \mathrm{GalC}^{-}$oligodendrocyte progenitors. Dev Biol 159:618-630.

Grissmer S, Nguyen AN, Aiyar J, Hanson DC, Mather RJ, Gutman GA, Karmilowicz MJ, Auperin DD, Chandy KG (1994) Pharmacological characterization of five cloned voltage-gated $\mathrm{K}^{+}$channels, types Kv1.1, $1.2,1.3,1.5$, and 3.1, stably expressed in mammalian cell lines. Mol Pharmacol 45:1227-1234.

Hertz L, Soliven B, Hertz E, Szuchet S, Nelson DJ (1990) Channelmediated and carrier-mediated uptake of $\mathrm{K}^{+}$into cultured oligodendrocytes. Glia 3:550-557.

Hwang PM, Fotuhi M, Bredt DS, Cunningham AM, Snyder SH (1993) Contrasting immunohistochemical localizations in rat brain of two novel $\mathrm{K}^{+}$channels of the Shab subfamily. J Neurosci 13:1569-1576.

Isacoff EY, Jan YN, Jan LY (1990) Evidence for the formation of heteromultimeric potassium channels in Xenopus oocytes. Nature 345:530-534.

Karschin A, Wischmeyer E (1995) Identification of G-protein-regulated inwardly rectifying $\mathrm{K}^{+}$channels in rat brain oligodendrocytes. Neurosci Lett 183:135-138.

Knutson P, Ghiani CA, Zhou J, Gallo V, McBain CJ (1997) $\mathrm{K}^{+}$channel expression and cell proliferation are regulated by intracellular sodium and membrane depolarization in oligodendrocyte progenitor cells. J Neurosci 17:2669-2682.

Kohler M, Hirschberg B, Bond CT, Kinzie JM, Marrion NV, Maylie J, Adelman JP (1996) Small-conductance, calcium-activated potassium channels from mammalian brain. Science 273:1709-1712.

Litman P, Barg J, Rindzoonski L, Ginsburg I (1993) Subcellular localization of tau mRNA in differentiating neuronal cells: implication for neuronal polarity. Neuron 10:627-638.

MacKinnon R (1991) Determination of the subunit stoichiometry of a voltage-gated potassium channel. Nature 350:232-235.

Matus-Leibovitch N, Vogel Z, Ezra-Macabee V, Etkin S, Nevo I, Attali B (1996) Chronic morphine administration enhances the expression of Kv1-5 and Kv1-6 voltage-gated $\mathrm{K}^{+}$channels in rat spinal cord. Mol Brain Res 40:261-270.

McCarthy KD, de Vellis J (1980) Preparation of separate astroglial and oligodendroglial cell cultures from rat cerebral tissue. J Cell Biol 85:890-902.

Mi H, Deerinck TJ, Ellisman MH, Schwarz TL (1995) Differential distribution of closely related potassium channels in rat Schwann cells. J Neurosci 15:3761-3774.

Mi H, Deerinck TJ, Jones M, Ellisman MH, Schwarz TL (1996) Inwardly rectifying $\mathrm{K}^{+}$channels that may participate in $\mathrm{K}^{+}$buffering are localized in microvilli of Schwann cells. J Neurosci 16:2421-2429.

Moscarello MA (1990) Myelin basic protein: a dynamically changing structure. In: Dynamic interactions of myelin proteins (Hashim GA, Moscarello M, eds), pp 25-48. New York: Liss.

Nilius B, Droogmans G (1994) A role for $\mathrm{K}^{+}$channels in cell proliferation. News Physiol Sci 9:105-110.

Pappas CA, Ullrich N, Sontheimer H (1994) Reduction of glial proliferation by $\mathrm{K}^{+}$channel blockers is mediated by changes in $\mathrm{pH}_{\mathrm{i}}$. NeuroReport 6:193-196.

Pongs O (1992) Molecular biology of voltage-dependent potassium channels. Physiol Rev 72:S69-S88. 
Roy ML, Saal D, Perney T, Sontheimer H, Waxman SG, Kaczmarek LK (1996) Manipulation of the delayed rectifier Kv1.5 potassium channel in glial cells by antisense oligodeoxynucleotides. Glia 18:177-184.

Ruppersberg JP, Schroter KH, Sakmann B, Stocker M, Sewing S, Pongs O (1990) Heteromultimeric channels formed by rat brain potassium channel proteins. Nature 345:535-537.

Salkoff L, Jegla T (1995) Surfing the DNA databases for $\mathrm{K}^{+}$channels nets yet more diversity. Neuron 15:489-492.

Sambrook J, Fritsch EF, Maniatis T (1989) Molecular cloning: a laboratory manual, 2nd Ed. Cold Spring Harbor, NY: Cold Spring Harbor Laboratory.

Scott VES, Muniz ZM, Sewing S, Lichtinghagen R, Parcej DN, Pongs O, Dolly JO (1994) Antibodies specific for distinct Kv subunits unveil a hetero-oligomeric basis for subtypes of alpha-dendrotoxin-sensitive $\mathrm{K}^{+}$ channels in bovine brain. Biochemistry 33:1617-1623.

Sheng M, Liao YJ, Jan YN, Jan LY (1993) Presynaptic A-current based on heteromultimeric $\mathrm{K}^{+}$channels detected in vivo. Nature 365:72-75.

Shrager P, Novakovic SD (1995) Control of myelination, axonal growth, and synapse formation in spinal cord explants by ion channels and electrical activity. Dev Brain Res 88:68-78.

Soliven B, Wang N (1995) Arachidonic acid inhibits potassium conductances in cultured rat oligodendrocytes. Am J Physiol 269:C341-C348.

Soliven B, Szuchet S, Arnason BGW, Nelson DJ (1988) Voltage-gated potassium currents in cultured ovine oligodendrocytes. J Neurosci 8:2131-2141.

Soliven B, Szuchet S, Arnason BGW, Nelson DJ (1989) Expression and modulation of $\mathrm{K}^{+}$currents in oligodendrocytes: possible role in myelinogenesis. Dev Neurosci 11:118-131.

Soliven B, Takeda M, Shandy T, Nelson DJ (1993) Arachidonic acid and its metabolites increase $[\mathrm{Ca}]_{i}$ in cultured rat oligodendrocytes. Am J Physiol 264:C632-C640.
Soliven B, Takeda M, Szuchet S (1994) Depolarizing agents and tumor necrosis factor- $\alpha$ modulate protein phosphorylation in oligodendrocytes. J Neurosci Res 38:91-100.

Sontheimer H (1994) Voltage-dependent ion channels in glial cells. Glia $11: 156-172$

Sontheimer H, Kettenmann H (1988) Heterogeneity of potassium currents in cultured oligodendrocytes. Glia 1:415-420.

Sontheimer H, Trotter J, Schachner M, Kettenmann H (1989) Channel expression correlates with differentiation stage during the development of oligodendrocytes from their precursor cells in culture. Neuron 2:1135-1145.

Stühmer W, Ruppersberg JP, Schroter KH, Sakmann A, Stocker M, Giese KP, Perschke A, Baumann A, Pongs O (1989) Molecular basis of functional diversity of voltage-gated potassium channels in mammalian brain. EMBO J 8:3235-3244.

Swanson R, Marshall J, Smith JS, Williams JB, Boyle MB, Folander K, Luneau CJ, Antanavage J, Olivia C, Buhrow SA, Bennet C, Stein RB, Kaczmarek LK (1990) Cloning and expression of cDNA and genomic clones encoding three delayed rectifier potassium channels in rat brain. Neuron 4:929-939.

Veh RW, Lichtinghagen R, Sewing S, Wunder F, Grumbach IM, Pongs O (1995) Immunohistochemical localization of five members of the Kv1 channel subunits: contrasting subcellular locations and neuron-specific colocalizations in rat brain. Eur J Neurosci 7:2189-2205.

Wang H, Kunkel DD, Martin TM, Schwartzkroin PA, Tempel BL (1993) Heteromultimeric $\mathrm{K}^{+}$channels in terminal and juxtaparanodal regions of neurons. Nature 365:75-79.

Wilson GF, Chiu SY (1993) Mitogenic factors regulate ion channels in Schwann cells cultured from newborn rat sciatic nerve. J Physiol (Lond) 470:501-520. 